\title{
Assessing the sustainability of pension reforms in Europe Aaron George Grech
}

\section{Contents}

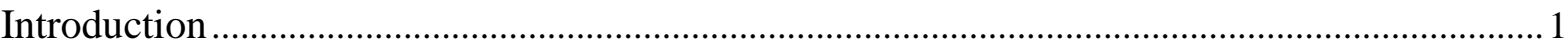

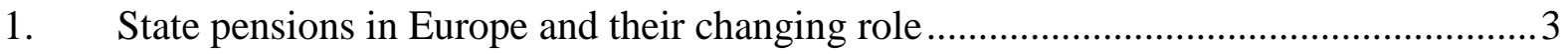

2. Defining and measuring pension system sustainability ........................................

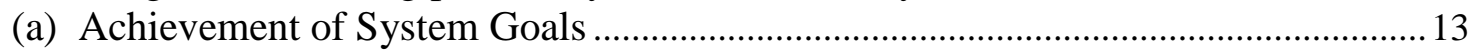

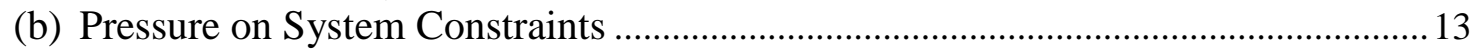

3. Applying empirically the pension system sustainability framework ........................... 14

4. Overall assessment of social sustainability of pension reforms ..................................20

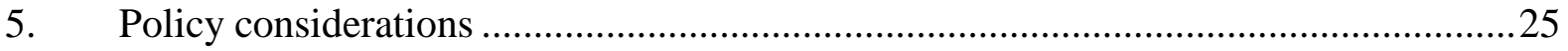

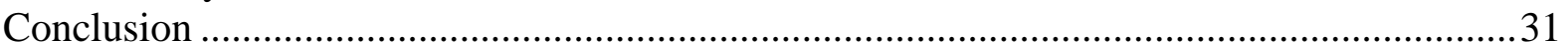

CASE/140

September 2010
Centre for Analysis of Social Exclusion

London School of Economics

Houghton Street

London WC2A $2 \mathrm{AE}$

CASE enquiries - tel: 02079556679 


\section{Centre for Analysis of Social Exclusion}

The Centre for the Analysis of Social Exclusion (CASE) is a multi-disciplinary research centre based at the London School of Economics and Political Science (LSE), within the Suntory and Toyota International Centres for Economics and Related Disciplines (STICERD). Our focus is on exploration of different dimensions of social disadvantage, particularly from longitudinal and neighbourhood perspectives, and examination of the impact of public policy.

In addition to our discussion paper series (CASEpapers), we produce occasional summaries of our research in CASEbriefs, and reports from various conferences and activities in CASEreports. All these publications are available to download free from our website. Limited printed copies are available on request.

For further information on the work of the Centre, please contact the Centre Manager, Jane Dickson, on:

Telephone: UK+20 79556679

Fax: $\quad$ UK+207955 6951

Email: $\quad$ j.dickson@lse.ac.uk

Web site: http://sticerd.lse.ac.uk/case

(c) Aaron George Grech

All rights reserved. Short sections of text, not to exceed two paragraphs, may be quoted without explicit permission provided that full credit, including (C) notice, is given to the source. 


\section{Editorial Notes and Acknowledgements}

Aaron George Grech is an Economic Advisor at the Department for Work and Pensions (UK). This paper summarises the main results of the doctoral research he carried out between September 2006 and May 2010 at the LSE's Centre for Analysis of Social Exclusion (CASE), where he is now a Visiting Research Fellow. For the work reported here, he is grateful to his principal supervisor, John Hills, for his ideas, criticism, constant attention, discipline and enthusiasm shown throughout his period as a PhD student affiliated to CASE. The paper also benefits from the comments of his associate supervisor, Nicholas Barr, whose research helped inspire the social sustainability concept developed by the author to assess pension reforms. This research would not have been possible in the absence of the excellent pension modelling work conducted by the OECD in recent years, and the author is particularly indebted to Monika Queisser and Edward Whitehouse, of the OECD's Social Policy Division, for having granted him access to the OECD's APEX model. The author also thanks CASE for providing accommodation and computing facilities and the LSE Department of Social Policy for academic guidance during his doctoral research.

The views expressed in this paper are those of the author, and organisations with which he is affiliated with do not carry any responsibility towards data used and interpretations made in the paper. The author also takes full responsibility for all errors and omissions. 


\begin{abstract}
Spurred by the ageing transition, many governments have made wide-ranging reforms, dramatically changing Europe's pensions landscape. Nevertheless there remain concerns about future costs, while unease about adequacy is growing. This study develops a comprehensive framework to assess pension system sustainability. It captures the effects of reforms on the ability of systems to alleviate poverty and maintain living standards, while setting out how reforms change future costs and relative entitlements for different generations.
\end{abstract}

This framework differs from others, which just look at generosity at the point of retirement, as it uses pension wealth - the value of all transfers during retirement. This captures the impact of both longevity and changes in the value of pensions during retirement. Moreover, rather than focusing only on average earners with full careers, this framework examines individuals at different wage levels, taking account of actual labour market participation. The countries analysed cover $70 \%$ of the EU's population and include examples of all system types.

Our estimates indicate that while reforms have decreased generosity significantly, in most, but not all, countries the poverty alleviation function remains strong, particularly where minimum pensions have improved. However, moves to link benefits to contributions have made some systems less progressive, raising adequacy concerns for women and those on low incomes. The consumption smoothing function of state pensions has declined noticeably, suggesting the need for longer working lives or additional private saving for individuals to maintain pre-reform living standards. Despite the reforms, the size of entitlements of future generations should remain similar to that of current generations, in most cases, as the effect of lower annual benefits should be offset by longer retirement. Though reforms have helped address the financial challenge faced by pension systems, in many countries pressures remain strong and further reforms are likely.

JEL Classification: H55, I38, J26.

Keywords: Social Security and Public Pensions; Retirement; Poverty; Retirement Policies.

Corresponding author: Aaron George Grech (a.g.grech@1se.ac.uk) 


\section{Introduction}

"Systems providing financial security for the old are under increasing strain throughout the world. Rapid demographic transitions caused by rising life expectancy and declining fertility mean that the proportion of old people in the general population is growing rapidly. Extended families and other traditional ways of supporting the old are weakening. Meanwhile, formal systems, such as government-backed pensions, have proved both unsustainable and very difficult to reform. In some developing countries, these systems are nearing collapse. In others, governments preparing to establish formal systems risk repeating expensive mistakes. The result is a looming old age crisis that threatens not only the old but also their children and grandchildren, who must shoulder, directly or indirectly, much of the increasingly heavy burden of providing for the aged."

Averting the old age crisis (World Bank 1994)

"Europe has started to prepare for these challenges, and encouraging progress has been made by some Member States.... However, without further institutional and policy changes, demographic trends are expected to transform our societies considerably, impinging on intergenerational solidarity and creating new demands on future generations. Such trends will have a significant impact on potential growth and lead to strong pressures to increase public spending.....Recent analysis confirms that there is a window of opportunity - a period of about ten years during which labour forces will continue to increase - for implementing the structural reforms needed by ageing societies. Taking no action would weaken the EU's ability to meet the future needs of an ageing population."

European Commission communication to the European Parliament and Council, 2009

"The stabilisation of public pension spending can be attained also by means of reducing future generosity of pension benefits....The decline in the public pension benefit ratio over the period 2008 to 2060 is substantial, $20 \%$ or more in 11 Member States....It is very difficult to assess to what extent future pension benefits will be 'adequate' in the future... The risk of a 'too small' pension must not be overstated by focusing on the drop in the benefit ratio..."

2009 Ageing Report (Economic Policy Committee 2009)

These quotations illustrate what is possibly the biggest social policy issue faced by governments across Europe. Having set up an intergenerational social contract through which workers finance significant transfers to the elderly on the assumption 
that future workers will do the same, ${ }^{1}$ policymakers have in recent decades increasingly worried about the system's sustainability. Spurred by the ageing transition, many governments have carried out wide-ranging reforms, changing the public pensions landscape in Europe dramatically since the early 1990s. Nevertheless concerns about future costs remain at the top of the agenda of most EU finance ministers. Yet, public resistance to reforms remains strong, with strikes, demonstrations and increasingly cases of reform reversals or modifications, reflecting concerns about the social impact of the reforms. In this light, it is evident that policymakers need to develop a more comprehensive framework with which to assess the sustainability of their pension systems. Such a framework would look at financial sustainability and intergenerational equity but also give due weight to the impact of reforms on the achievements of their pension systems. As suggested by the quotations above, policymakers seem unsure of how to quantify and weigh against each other the different risks reforms face.

Most pension reforms have been driven by a rather limited concept of sustainability, conceived as reducing projected levels of future spending on state pensions, through cuts in generosity. However, given the growing size of the pensioner population, there is an increasing risk that if the pension system does not fulfil public expectations, and/or older people find that they did not make appropriate saving and working decisions, the state could be forced by voters to reverse reforms and spend more on social transfers. Rather than focusing only on the effect of reforms on projected spending on pensions, assessments of reforms should also attempt to understand the implications of reforms on pension adequacy, particularly on entitlements of those population groups less able to accommodate the effects of benefit cuts through behavioural changes. The long-term sustainability of recent pension reforms depends crucially on their impact on the pension system's ability to reduce poverty and replace pre-retirement income and also on the ability of individuals to change their work and saving behaviour to accommodate the effects of reforms.

This paper will develop this broader concept of social sustainability, and present evidence on pension reforms in ten European countries. ${ }^{2}$ At present, most studies on adequacy look at theoretical replacement rates at the point of retirement, while studies on financial sustainability concentrate on projected spending on pensions as a percentage of the national output in a future year. However, these approaches are not appropriate in light of the continued increase in longevity. An individual in future might be getting a pension which provides a lower replacement rate in any one year than under current rules, but still get the same amount of total transfers over the whole lifetime. ${ }^{3}$ Similarly the impact of an increase in longevity on the level of pension

1 This method of financing pensions is known as Pay-As-You-Go (PAYG) funding.

As explained later on, these countries were chosen not just on the basis of them having enacted significant reforms. The countries were also chosen so that there would be examples of all pension system designs and of the main types of reforms carried out across Europe since the start of the 1990 s.

This is particularly important when looking at systemic pension reforms, such as those in Sweden and Poland - which result in annual pension benefits changing automatically with demographic developments. 
spending builds up over time and cannot be captured fully by just looking at spending in a particular year. To assess the effective impact of reforms, one needs to look at a more sophisticated indicator of generosity, pension wealth - the value of all the prospective pension transfers received by an individual. This is not only a more comprehensive adequacy measure, but since it can also be used to determine the overall liabilities faced by governments, provides a direct link between adequacy and fiscal sustainability. Most studies, by contrast, compute adequacy and fiscal indicators separately.

Another analytical failing of existing literature which this paper will try to address is the tendency to focus on pension outcomes for men who have had a full career at average earnings. This paper will show that this can be very misleading, both when assessing the outcomes of a current system and the possible impacts of pension reforms. ${ }^{4}$ Instead the approach taken in this paper will be to look at individuals of both genders across the whole of the income distribution and with careers which are more representative of actual labour market participation in their economies.

The paper is divided in five sections. In the first, it summarises the evidence of the current role of state pensions in Europe and outlines their changing role. It then develops the concept of social sustainability and describes how this can be assessed by means of four indicators - based on pension wealth measures. The third section applies this framework by looking at reforms legislated in ten European countries between the early 1990s and 2008, and the overall assessment of social sustainability of country reforms synthesised in section 4 . Finally the paper looks at the policy implications of these results, outlining the extent of changes in saving and labour market participation which could help sustain state pension reforms and also setting out the remaining challenges for the ten pension systems reviewed.

\section{State pensions in Europe and their changing role}

There are significant differences in the size and design of state pension systems across Europe. Table 1 summarises these system design differences by setting out how state pension benefits are determined. At present, the dominant model remains defined benefit - where pensions are defined as some fraction of previous income. However, throughout the 1990s several countries have shifted to defined contribution formulae where benefits are linked to contributions made and projected longevity. In particular, in most of Eastern Europe labour market entrants now depend mostly on personal accounts for their main retirement provision. 
Table 1: Benefit-determination taxonomy of state pension systems in the EU

\begin{tabular}{|c|c|c|c|c|c|c|}
\hline & $\begin{array}{c}\text { Contribution- } \\
\text { based, } \\
\text { Flat-rate }^{1}\end{array}$ & $\begin{array}{l}\text { Residence- } \\
\text { based, } \\
\text { Flat-rate1 }\end{array}$ & $\begin{array}{c}\text { Notional } \\
\text { Defined } \\
\text { Contribution }^{2}\end{array}$ & $\begin{array}{l}\text { Defined } \\
\text { Benefit }^{3}\end{array}$ & Points ${ }^{4}$ & $\begin{array}{c}\text { Defined } \\
\text { Contribution } \\
\text { personal } \\
\text { accounts }^{2} \\
\end{array}$ \\
\hline Austria & & & & $\mathrm{X}$ & & \\
\hline Belgium & & & & $\mathrm{X}$ & & \\
\hline Greece & & & & $X$ & & \\
\hline Spain & & & & $X$ & & \\
\hline Portugal & & & & $X$ & & \\
\hline Slovenia & & & & $X$ & & \\
\hline Malta & & & & $X$ & & \\
\hline France & & & & $X$ & $X$ & \\
\hline Germany & & & & & $X$ & \\
\hline Romania & & & & & $X$ & \\
\hline Luxembourg & $X$ & & & $X$ & & \\
\hline UK & $X$ & & & $X$ & & \\
\hline Czech Rep & $X$ & & & $X$ & & \\
\hline Cyprus & $X$ & & & $X$ & & \\
\hline Lithuania & $X$ & & & $X$ & & $X$ \\
\hline Bulgaria & & & & $X$ & & $X$ \\
\hline Hungary & & & & $X$ & & $X$ \\
\hline Ireland & $\mathrm{X}$ & & & & & \\
\hline Finland & & $X$ & & $X$ & & \\
\hline Netherlands & & $X$ & & $X$ & & \\
\hline Estonia & & $X$ & & $X$ & & $X$ \\
\hline Denmark & & $X$ & & & & $X$ \\
\hline Sweden & & $X$ & $X$ & & & $X$ \\
\hline Poland & & & $X$ & & & $X$ \\
\hline Latvia & & & $X$ & & & $X$ \\
\hline Italy & & & $X$ & & & \\
\hline
\end{tabular}

1. Under a flat-rate system, all those who meet the set conditions (either a given amount of contributions paid or a period of residence in a country) get paid the same benefits.

2. Under a defined contribution system, benefits are determined by the contributions made (and any return on them) and by the expected length of retirement. While in personal account systems, contributions are invested in financial markets, notional account systems are PAYG.

3. In a defined benefit system, benefits are a ratio of a set salary - the final salary, the average lifetime salary or an intermediate figure - on which contributions were paid.

4. Under a points system, entitlement is based on pension points accumulated. A year's contribution at the average earnings earns one point. Points are multiplied by a pension value to determine the monthly benefit.

Note: Many countries are in some form of transition due to reforms, or to partial maturation of schemes. For classification purposes only rules as apply to new labour market entrants were considered. Only mandatory/quasi-mandatory provision was taken into account.

Source: Own analysis using information in Economic Policy Committee (2007). 
The differences in pension system designs are also reflected in the size of state pension outlays. Across the EU, state pension spending constituted more than a fifth of total government outlays in 2007, equivalent to over a tenth of national output. There is considerable variation in state pension spending across the EU, ranging from 4\% of GDP in Ireland to 14\% of GDP in Italy, but in all countries pensions feature prominently. Moreover Figure 1 suggests that the expansion of state pensions does not solely reflect the expansion of state activity. State pension spending is high in countries, like Denmark and Sweden, with high overall public spending, but also in countries, such as Luxembourg and Poland, with a much smaller public sector. The similarity in pension expenditure levels is even more evident when one includes spending on occupational pension schemes. ${ }^{5}$

Figure 1: Government spending and the share of state pensions (2007)

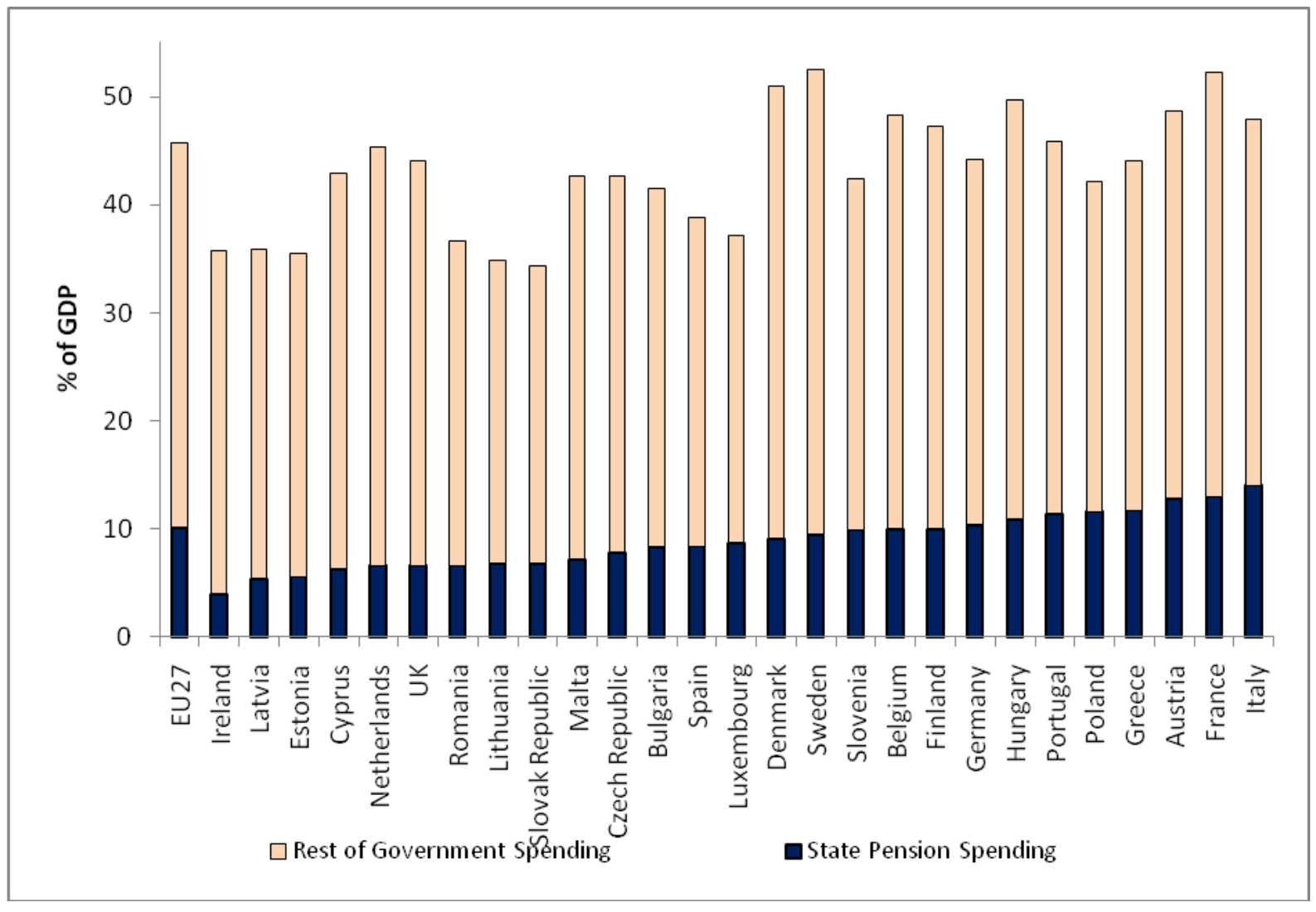

Note: Countries arranged in order of the size of state pension spending.

Source: Eurostat and Economic Policy Committee (2009).

Data on incomes show that while they fall with age, the drop following retirement is not dramatic in most European countries. Across the EU25 in 2005-07, elderly people had a median income equal to $86 \%$ that of the working age population. Existing evidence suggests pensions are the main source of income for people aged over 65 . There are some differences as to the relative importance of the state, but this is limited

For instance, data from Eurostat's European System of Integrated Social Protection Statistics (ESSPROS) confirm that in the UK and the Netherlands, where provision has traditionally been allocated partially to employers, overall spending is comparable to that in countries with state-only provision. 
to middle-to-high income groups, as can be seen in Table 2. In the entire EU, low income individuals depend crucially on the state for support.

Table 2: Sources of income* of people aged 65 to 74, by income group (\% of total) - 2003

\begin{tabular}{|l|cccc|cccc|cccc|}
\hline & \multicolumn{4}{|c|}{ Bottom 20\% } & \multicolumn{3}{c|}{ Middle 60\% } & \multicolumn{3}{c|}{ Top 20\% } \\
\cline { 2 - 13 } & Work & Priv & $\begin{array}{c}\text { Old } \\
\text { age } \\
\text { ben }\end{array}$ & $\begin{array}{c}\text { Oth } \\
\text { ben }\end{array}$ & Work & Priv & $\begin{array}{c}\text { Old } \\
\text { age } \\
\text { ben }\end{array}$ & $\begin{array}{c}\text { Oth } \\
\text { ben }\end{array}$ & Work & Priv & $\begin{array}{c}\text { Old } \\
\text { age } \\
\text { ben }\end{array}$ & $\begin{array}{c}\text { Oth } \\
\text { ben }\end{array}$ \\
\hline Denmark & 2 & 7 & 79 & 12 & 12 & 8 & 74 & 6 & 32 & 12 & 54 & 2 \\
Greece & 10 & 3 & 82 & 4 & 9 & 5 & 84 & 2 & 13 & 12 & 75 & 0 \\
Sweden & 1 & 2 & 83 & 14 & 4 & 3 & 91 & 2 & 16 & 7 & 76 & 1 \\
Portugal & 5 & 1 & 85 & 9 & 17 & 2 & 77 & 4 & 23 & 7 & 70 & 1 \\
UK & 2 & 4 & 85 & 9 & 8 & 8 & 76 & 8 & 23 & 17 & 59 & 1 \\
Ireland & 5 & 2 & 86 & 8 & 20 & 4 & 72 & 4 & 48 & 11 & 41 & 0 \\
Austria & 0 & 3 & 86 & 11 & 1 & 2 & 92 & 5 & 7 & 5 & 84 & 4 \\
Finland & 3 & 1 & 86 & 10 & 9 & 4 & 79 & 8 & 26 & 7 & 62 & 5 \\
Spain & 3 & 2 & 88 & 6 & 6 & 4 & 87 & 3 & 21 & 10 & 66 & 3 \\
France & 1 & 5 & 89 & 4 & 3 & 6 & 90 & 2 & 4 & 8 & 86 & 1 \\
Italy & 2 & 1 & 89 & 8 & 5 & 2 & 89 & 5 & 25 & 7 & 65 & 3 \\
Germany & 1 & 3 & 91 & 4 & 4 & 4 & 90 & 1 & 12 & 10 & 77 & 1 \\
Luxembourg & 1 & 1 & 91 & 7 & 2 & 6 & 88 & 4 & 9 & 19 & 69 & 3 \\
Netherlands & 1 & 1 & 91 & 7 & 1 & 3 & 92 & 4 & 4 & 6 & 88 & 1 \\
Belgium & 1 & 3 & 92 & 4 & 4 & 7 & 87 & 1 & 21 & 24 & 54 & 0 \\
\hline
\end{tabular}

Note: Countries arranged in order of the importance of old age benefits for the bottom $20 \%$.

* Old age benefits includes all social protection transfers intended to protect against the risks of old age - including state and occupational pensions, survivors benefits and in kind benefits. Other benefits include social assistance, housing benefits and disability benefits.

Source: Zaidi et al (2006).

Barr and Diamond (2006) argue that "from an individual viewpoint, income security in old age requires two types of instruments: a mechanism for consumption smoothing, and a means of insurance". ${ }^{6}$ Furthermore they observe that "a second reason for government involvement is that public policy generally has objectives additional to improving consumption smoothing and insurance, notably poverty relief and redistribution". Income survey data indicate that there are noticeable differences in the poverty alleviation and income replacement effects of the different retirement income schemes in Europe, and suggest that having similar institutional designs does not necessarily lead to similar income smoothing or poverty reduction. For instance, both Austria and Greece have a defined benefit state pension system, but the relative poverty rate among the elderly in Greece is nearly twice as high as in Austria.

6 Whitehouse (2007) makes the same argument and, in fact, classifies the pension schemes of different countries on the basis of these two functions. 
Table 3: Differences in poverty alleviation and income replacement of pensions (2005-2007)

\begin{tabular}{|c|c|c|c|c|c|c|c|}
\hline & \multicolumn{3}{|c|}{ Relative income $^{1}$} & & \multicolumn{3}{|c|}{ Relative poverty $^{2}$} \\
\hline & Male & Female & All & & Male & Female & All \\
\hline EU25 & 89 & 83 & 86 & EU25 & 16 & 21 & 19 \\
\hline Cyprus & 62 & 57 & 56 & Cyprus & 48 & 54 & 51 \\
\hline Ireland & 67 & 66 & 65 & Ireland & 26 & 33 & 30 \\
\hline Estonia & 71 & 66 & 68 & Spain & 27 & 32 & 29 \\
\hline Latvia & 77 & 75 & 68 & Latvia & 17 & 34 & 28 \\
\hline Denmark & 73 & 71 & 69 & UK & 25 & 30 & 28 \\
\hline UK & 70 & 68 & 69 & Portugal & 26 & 27 & 27 \\
\hline Belgium & 72 & 73 & 72 & Greece & 23 & 27 & 26 \\
\hline Finland & 79 & 70 & 72 & Estonia & 15 & 32 & 26 \\
\hline Lithuania & 79 & 67 & 73 & Lithuania & 10 & 29 & 23 \\
\hline Spain & 75 & 74 & 73 & Belgium & 21 & 24 & 22 \\
\hline Portugal & 81 & 75 & 77 & Italy & 18 & 25 & 22 \\
\hline Sweden & 84 & 73 & 77 & Finland & 15 & 24 & 21 \\
\hline Malta & 79 & 80 & 78 & Slovenia & 11 & 25 & 20 \\
\hline Czech Rep & 80 & 78 & 80 & Malta & 22 & 19 & 20 \\
\hline Greece & 85 & 79 & 81 & Denmark & 16 & 19 & 18 \\
\hline Slovakia & 86 & 79 & 82 & Germany & 12 & 17 & 15 \\
\hline Italy & 87 & 82 & 83 & Austria & 10 & 18 & 15 \\
\hline Netherlands & 88 & 85 & 83 & France & 14 & 17 & 15 \\
\hline Slovenia & 92 & 79 & 84 & Sweden & 7 & 14 & 11 \\
\hline France & 92 & 88 & 87 & Luxembourg & 8 & 8 & 8 \\
\hline Germany & 89 & 87 & 88 & Poland & 6 & 9 & 8 \\
\hline Austria & 97 & 89 & 90 & Slovakia & 3 & 11 & 8 \\
\hline Luxembourg & 88 & 87 & 94 & Hungary & 5 & 9 & 7 \\
\hline Hungary & 99 & 88 & 95 & Netherlands & 7 & 8 & 7 \\
\hline Poland & 110 & 95 & 103 & Czech Rep & 2 & 8 & 5 \\
\hline
\end{tabular}

1. Relative income ratios of elderly people by gender - median equivalised incomes of $65+$ by gender as $\%$ of that of the working age population by gender Countries arranged according to the size of their relative income ratio for the $65+$. Countries with a below-EU average relative income ratio are in italics.

2. Percentage of the $65+$ population with an income less than $60 \%$ of median equivalised disposable income in that country. Countries ordered according to the size of the poverty rate of their $65+$ population. Countries with a poverty rate higher than the EU25 average are in italics.

Source: Own analysis using EU-SILC (2005-07). 
Consequently, rather than focusing on institutional features, it makes sense to investigate how the outcomes of pension systems are linked, so to understand better the real differences between countries' pension systems and help determine how reforms may change system performance. Given the above considerations that pension spending is the largest item in government budgets and that its main goals are income replacement and poverty alleviation, in Figure 2 we categorise pensions systems focusing on these three dimensions. Countries where pension spending as a percentage of the national output is higher (e.g. Italy) than the EU average are deemed to be high spenders, and are placed above the horizontal line in the Figure, and vice versa (e.g. Ireland). Similarly countries where the proportion of elderly with an income below the relative poverty threshold is higher than the EU average are placed to the left of the vertical line (e.g. Italy), and vice versa (e.g. Sweden). So, for instance, since Poland spends more than the EU average on state pensions and the poverty risk among its elderly is below the EU average, it is categorised in the upper right quadrant of the Figure. By contrast, Ireland, a country with lower-than-average pension spending and higher-than-average risk of pensioner poverty, is placed within the lower left quadrant. The other dimension of this pension system categorisation is illustrated by means of a darker shading of countries where the relative income ratio of elderly persons is above the EU25 average, typically because of a high replacement ratio of pensions. Thus Poland is in the darker shaded area, while Ireland is in the lighter shaded one. Given that countries with high relative income ratios tend to have lowerthan-average risk-of-poverty and higher-than-average spending, the darker shading occurs mostly in the upper right quadrant. Some countries, which seem to be moving away from their current position in relation to the EU average, are placed closer to the intersections of the sets in Figure 2.

This process results in the identification of three relatively distinct groups of countries, depicted in Figure 1. Group A (e.g. Germany, France, Austria, Poland, Hungary) are characterised by high levels of income replacement and low pensioner poverty, but high spending. At the other extreme, Group B countries have both low levels of income replacement and high rates of pensioner poverty. Countries in this group can be further divided into those with high (e.g. Italy) and low levels (e.g. UK) of state pension spending. Group C (e.g. Sweden, Finland, Slovakia) is at an intermediate position, with relatively low levels of spending and low rates of relative poverty among pensioners, but also low levels of income replacement in retirement. The importance of this new taxonomy is that it helps in understanding the possible sources of system stress - namely high spending in Group A, high poverty in Group $\mathrm{B}$, and low replacement in Group C. Thus, a priori, one might expect that reforms in countries of Group A would have focused on curbing expenditure; reforms in countries of Group $\mathrm{C}$ to have concentrated on improving income replacement; and reforms in countries of Group B to have been focused on two aspects: in countries with high spending - the curbing of spending followed by measures to tackle poverty and income replacement, and in countries with low spending - the expansion of the pension system. 


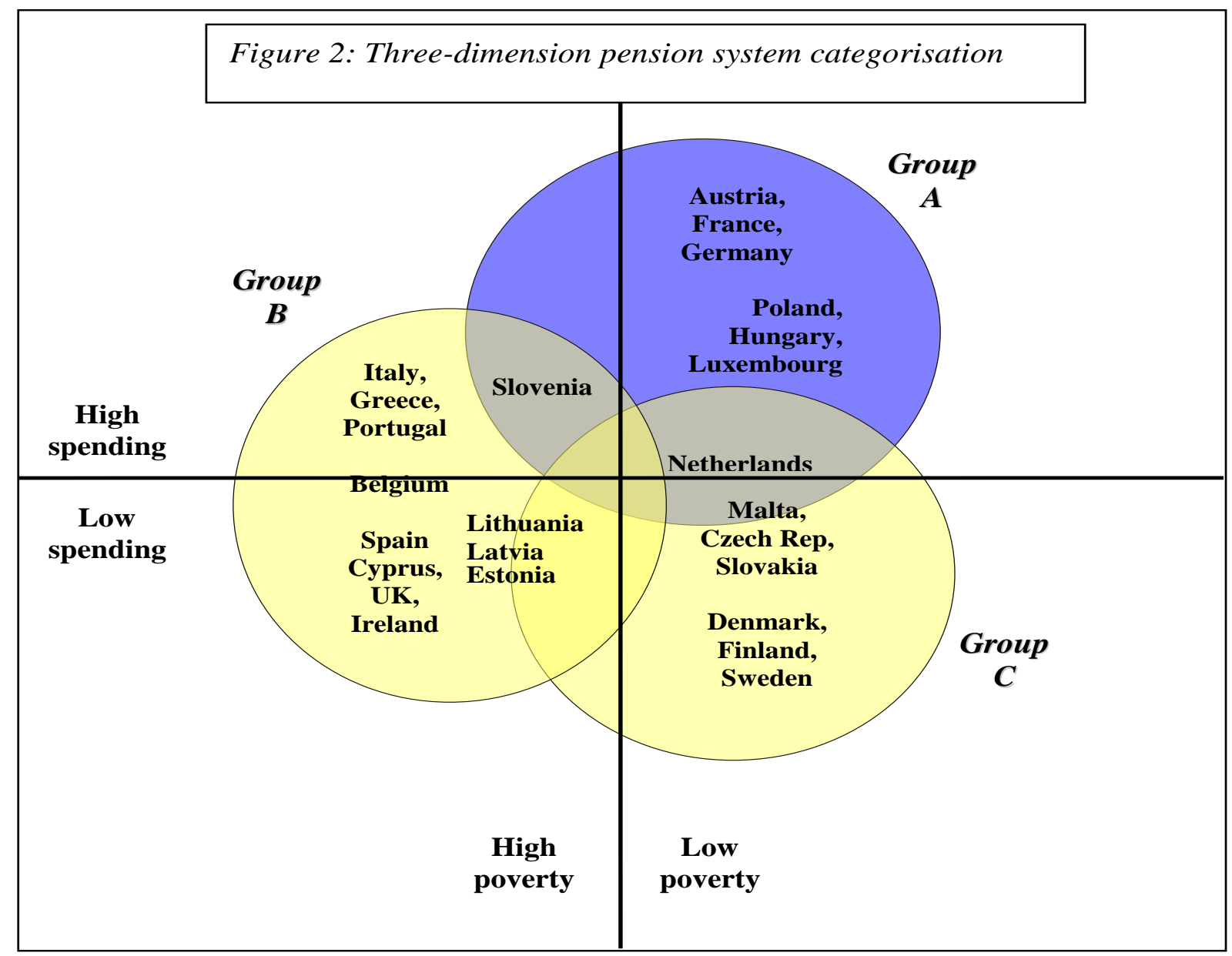

Note: Groups B and C are both shaded lightly, as countries classified in these groups have low replacement rates; while those in Group A have high replacement rates. Countries placed above the horizontal line are high spenders on state pensions. Countries placed to the left of the vertical line have higher-than-average elderly poverty. The position of the countries in these groups reflects the extent to which their level of pension spending, relative income of the elderly and percentage of elderly population at risk-of-poverty differs from the EU average.

However, most reviews of the pension reforms in Europe enacted since the 1990s show that the main consideration was long-term financial cost (and in some cases, especially in Eastern Europe, short-term financial problems and a desire to reduce the state's role). ${ }^{7}$ The impact of reforms on the capability of pension systems to achieve their aims has tended to be ignored or not given primary importance.

\section{Defining and measuring pension system sustainability}

The notion that sustainability is achieved solely by cutting future spending is, however, far too simplistic. While there is consensus that ageing populations are a challenge for pension systems, the achievement of reduced growth in spending cannot be seen as the definitive solution to ageing. As Zaidi (2006) points out "policy-makers 
need to remember that pensions were not introduced by chance". 8 Spending on pensions is but a means to an end - the alleviation of poverty and the provision of income replacement during retirement. While spending is an important constraint, having low spending should not be elevated to the status of an objective. A pension system is not successful just because it involves little spending - a successful system is that which achieves its goals with the least pressure on constraints.

Howse (2004) argues that most pension reformers are constrained by the belief that "the level of public expenditure as a proportion of GDP is already approaching the limits of political acceptability and economic efficiency" and that thus it is unfeasible to try to maintain the current situation by increasing taxes or pension contributions or by using public borrowing. However, he argues that even if this were correct, this "does not mean, of course, that the policy task is simply that of ensuring that these limits are not transgressed", but that "the real problem for governments is how to ensure that people have adequate income in retirement without transgressing these limits".

The importance of this reasoning is increasingly being recognised. In its 2006 report on long-term sustainability, the European Commission notes that while declining pension generosity can contribute positively to fiscal sustainability, "such a decrease may raise concerns about the adequacy of public pensions that could translate into pressure for higher public spending". The report also acknowledges that there is no great escape by simply reducing public responsibility and recognises that "the risks to public finances will crucially depend on the reaction of individuals regarding their future retirement arrangements". 9 Much in the same vein, Holzmann and Hinz (2005) present the revised World Bank position on pension reform arguing that "the primary goals of a pension system should be to provide adequate, affordable, sustainable, and robust retirement income". Pension systems should provide "benefits to the full breadth of the population that are sufficient to prevent old-age poverty on a countryspecific absolute level in addition to providing a reliable means to smooth lifetime consumption for the vast majority of the population."

While financial sustainability is an important factor underlying the sustainability of a reform, simply focusing on it alone is seriously inadequate as by doing so, one fails to take into account what pension systems are expected to achieve. By adopting a narrow vision of spending on pensions, this approach also fails to take into account potential feedback effects on fiscal spending from the impact of reforms on pension system adequacy. Fiscal sustainability and pension system adequacy are not conflicting aims, but rather two sides of the same coin. Real fiscal sustainability cannot be achieved without ensuring pension system adequacy. If pension systems fall short, there could be strong political pressure for higher government spending on other support.

See Ove Moene and Wallerstein (2003) for a discussion of why public pensions were set up namely whether they represent a struggle for redistribution or a desire to have protection against particular risks.

European Commission (2006). 
There appear to be four concerns in terms of ensuring pension system sustainability. From a political economy perspective, the adequacy of the system for the average voter needs to be ensured. If a system is not seen as beneficial by the electoral majority, namely by not helping them maintain their pre-retirement living standards, it could be voted out. Similarly if a system is not seen as able to alleviate poverty, the political pressures that led to the setting up of social assistance to elderly people during the early part of the twentieth century might re-emerge. In the process of achieving these two goals, policymakers need, however, to take into consideration the balance of transfers between different generations. Political pressures for reform can arise either because systems are not achieving the goals that individuals expect of them or because individuals are unhappy about the deal they are getting compared to previous generations. Individuals can be concerned about the level of taxes they pay to finance the system but also by the level of their pension transfers compared to previous generations. Social sustainability can only be achieved if policymakers understand these tradeoffs and optimise pension systems in this light. ${ }^{10}$ Figure 3 summarises this discussion.

Figure 3: Fiscal sustainability and pension adequacy - Two sides of the same coin

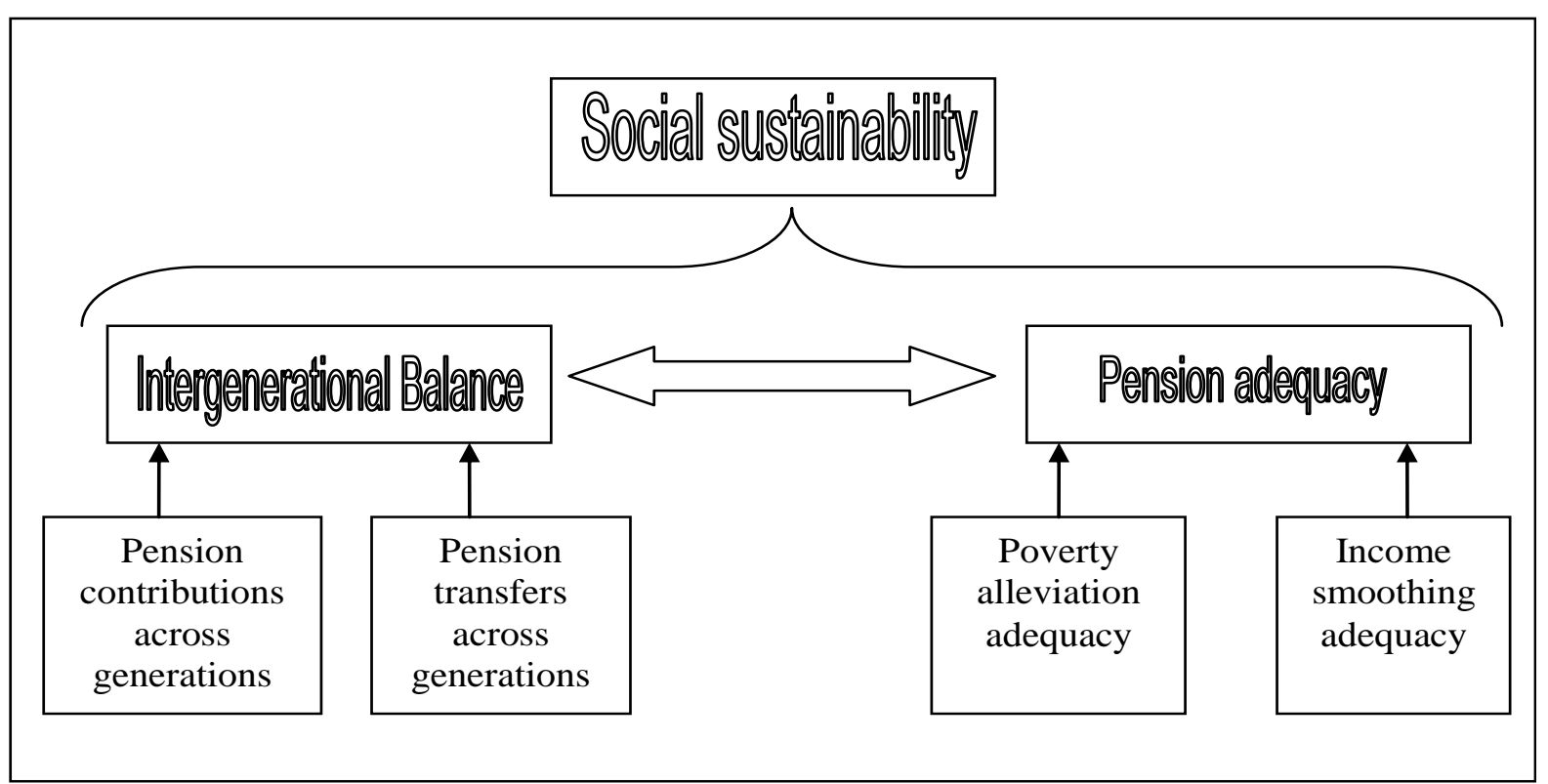

By contrast, up to now, evaluations of pension reform have either focused on pension spending projections or on the effect on theoretical replacement rates for full-career individuals on average earnings. The latter have been widely used as measures of adequacy. However, they suffer from a number of important deficiencies, such as being limited to single point-in-time comparisons and failing to capture the impact of changes in longevity. Similarly the full impact of longevity cannot be discerned by looking at single year projections of pension spending. Moreover spending projections and theoretical replacement rates have tended to be computed separately and in many cases, trends cannot be reconciled. particularly as regards economic growth and longevity. 
We contend that a better approach to evaluate pension reforms is to estimate pre- and post-reform pension wealth. The latter is the discounted stream of future pension payments during retirement, weighted by the probability that the individual will still be alive at that particular age. This measure captures the total pension transfer to an individual and is superior to replacement rates, as it captures the effects of benefit indexation post-retirement and of longevity. Pension wealth can be used to assess whether these transfers would result in individuals, on average, having an annual income that keeps them out of relative poverty during retirement, and also to calculate more accurately the degree of consumption smoothing that pension systems allow. Replacement rates at the point of retirement cannot do this as they fail to consider changes in the relative value of pensions over the retirement period. By comparing the pension wealth of two successive generations one can also arrive at an intuitive measure of intergenerational balance. Moreover, in conjunction with demographic and labour market data, pension wealth can be used to assess the long-term contribution rate needed to keep the pension system in financial balance across generations. This is a better measure of financial sustainability than focusing on projected spending on pensions (as a \% of GDP) in one particular year as it takes into account the fact that longer-lived generations will require this spending for more years.

As an empirical application of this framework, we estimated measures of pension wealth in 2005 and 2050 for hypothetical individuals under pre- and post-reform systems using the OECD's APEX cross-country pension entitlement model. ${ }^{11}$ In contrast with many other studies which just look at average male earners, we look at nine hypothetical individuals for each gender working full-time but at the different deciles of the wage distribution in each country, together with a hypothetical part-time worker (earning the median part-time wage) and an individual on minimum pension provision for each gender. ${ }^{12}$ Looking at different individuals is important as many pension systems are non-linear, and one cannot discern the poverty alleviation function of pensions by looking at average male earners. The benchmark for comparison was taken to be the situation in 2005 - when the pensioner generation was retiring under the pre-reform systems. By 2050, individuals were assumed to retire under the post-reform systems, while living longer lives.

Pension wealth estimates were estimated for ten countries. The latter, namely Austria, Finland, France, Germany, Hungary, Italy, Poland, Slovakia, Sweden and the UK, not only cover $70 \%$ of the EU's population, but also span the four different pension typologies developed in Section 1 of this paper and include examples of various types

The APEX (Analysis of Pension Entitlements across countries) model was originally developed by Axia Economics, with the help of funding from the OECD and the World Bank. The model codes detailed eligibility and benefit rules for mandatory pension schemes based on available public information that has been verified by country contacts. It provides most of the results reviewed in OECD's biennial 'Pensions at a Glance' publication (see OECD (2005), OECD (2007) and OECD (2009) and Whitehouse (2007).

Wage data are from Eurostat's Structure of Earnings Survey 2002, and represent the annual wages of workers in most of the private sector (excluding farming and fishing). 
of reforms. The reforms modelled were introduced between the early 1990s and $2008 .^{13}$

Pension wealth estimates were used to calculate four social sustainability indicators, on a pre- and post-reform basis, as follows:

\section{(a) Achievement of System Goals}

$>$ Strength of Poverty alleviation function $=$ We assess the poverty threshold (average annual pension as a percentage of national disposable income) pension wealth, defined net of income taxes and social security contributions, of the hypothetical individuals would sustain through retirement. In this case we looked only at hypothetical individuals of each gender with below-median wages, and computed an aggregate indicator which is a weighted average of poverty thresholds achieved (with the weights dependent on the relative size of that group out of the total working age population). To simplify cross-country comparisons, we recalibrated the EU's relative poverty threshold - which stands at $60 \%$ of national disposable income - to be equivalent to $35 \%$ of the average full-time wage in each country.

$>$ Strength of Consumption Smoothing function $=$ We assess how the annual average pension transfer implied by pension wealth, net of income taxes and social security contributions, would compare to pre-retirement wages. This in essence is the average replacement rate sustained throughout retirement by net pension wealth at the point of retirement. The ratio is calculated for all employed hypothetical individuals and then a weighted average (dependent on the relative size of that group out of the total employed) is taken as the aggregate indicator for that country.

\section{(b) Pressure on System Constraints}

$>$ Intergenerational Balance $=$ We express the pension wealth (weighted average for all our employed hypothetical individuals), defined in terms of the contemporary average wage, of the 2050 pensioner generation as a percentage of that of the 2005 generation.

$>$ Financial Sustainability $=$ We estimate the contribution rate out of the lifetime median wage required to pay aggregate gross pension wealth of the 2005 and 2050 pensioner generations. To do this, we compute the average gross pension wealth (weighted average for all the employed hypothetical individuals) of a generation and multiply this by the ratio of beneficiaries to contributors at the time.

In our modelling we assumed that there is full take-up of minimum pensions and that no private retirement saving is taking place - strong assumptions for countries with means-testing and significant private pension saving as take-up of benefits and the level of savings clearly affect state entitlements. Moreover our modelling skirted the 
issue of household formation and calculated entitlements to single individuals, ignoring entitlements arising from the labour participation of their partners. The estimates also ignore the effects on entitlements of credits provided for noncontributory periods - such as unemployment and childcare. These two simplifications can affect significantly results - especially for women. Finally, the indicators presented here assume pension wealth is transferred equally throughout retirement. In practice, transfers tend to be higher during the earlier part of retirement.

The main contribution of this analysis lies in four methodological innovations. Firstly, it uses pension wealth - a measure of overall generosity of transfers throughout retirement - rather than measures of generosity at the point of retirement. This captures the impact of two elements, namely longevity and indexation rules, which tend to be ignored despite that they have important consequences for the achievement of system goals and pressures on system constraints. The second innovation is the explicit use of benchmarks against which to assess pension entitlements. Most frequently policy makers have not sought to look at benchmarks in this area, preferring to retain a good level of discretion on what constituted 'adequate' outcomes. While the benchmarks used here can be seen as arbitrary, the framework is flexible enough to allow the testing of various outcomes. The third innovation is to attempt to measure all elements using the same indicators instead of using different models. This increases transparency and also clearly illustrates the trade-offs between system goals and constraints. Finally this framework is able to incorporate distributional and gender analysis - an element of pension reform assessment that has frequently not been given enough importance by policymakers.

\section{Applying empirically the pension system sustainability framework}

Even when they look beyond the average male earner, most assessments of pension reforms assume full careers in full-time employment. This assumption, though analytically convenient, is unrealistic and poses problems for our proposed sustainability framework. The assumption of complete careers till pension age overrepresents the real efficacy of existing pension systems, by over-estimating the achievement of goals, since it implies that individuals benefit from the maximum generosity of the system, while diminishing the constraints faced, as it boosts the support ratio (as everyone is assumed to be in work). Moreover, reformers may have based their policy choices on the understanding that there would be developments in the labour market which would offset part of the effects of their reforms. To provide adequately effective answers to the empirical questions of whether pension reforms are socially sustainable and what are the required changes for individuals to maintain living standards, one needs to move away from the full-career assumption and adopt more representative labour market assumptions.

The most desirable approach would be to estimate pension entitlements for our hypothetical individuals on the basis of actual and projected career lengths. However lack of comparable (cross-country) data on contribution records raises significant issues. This paper presents two sets of sustainability indictors. In the first set - the "full-careers" assumption - we focus on just the nine hypothetical full-time 
individuals of each gender and assume that they work from age 20 to the state pension age in their country. We also assume that everyone of working age is in employment. In the second set - the "actual careers" assumption - we look at all eleven cases (thus including the representative part-time worker and the person on minimum provision in addition to the nine full-timers). Moreover instead of assuming full-careers for those in employment, estimates of the number of years spent in the labour market were constructed using EU LFS current and projected ${ }^{14}$ participation rates by age. ${ }^{15}$ While still subject to significant caveats, ${ }^{16}$ these estimates should present a more realistic view of the present and future efficacy of pension systems being studied, as current and projected labour participation rates, particularly among women, differ greatly among the ten countries. There are also interesting cross-country differences in parttime employment. The aggregate results for the four sustainability indicators are presented for both the "full-careers" and "actual-careers" assumption in Tables 4 to 7, below.

Our estimates suggest that while reforms have reduced the poverty alleviation and consumption smoothing functions in nearly all countries, generosity remains high in most of them, with pension transfers keeping most of those below median earnings above the $60 \%$ relative poverty threshold, on average, throughout retirement. Reforms have mostly followed existing system goals, but with an eye to reduce future cost. However there have been some reforms, mostly in Eastern Europe, which may have raised issues about the future adequacy of pension systems for women and those on lower incomes as the degree of progressiveness has been reduced considerably. The "actual careers" estimates, however, confirm that the interaction between the labour market and the social protection system needs to be considered by researchers and policymakers alike. A system may look very generous on paper, but not be so in reality if only few individuals qualify for full benefits. This tends to be particularly pertinent for women. The "full-career estimates" of the strength of the poverty alleviation function are far lower than those resulting when adopting more realistic labour market assumptions (see Table 4). For instance, the poverty threshold currently provided, on average, by the French pension system ${ }^{17}$ drops to $63 \%$ from $73 \%$ among men and from $67 \%$ to $44 \%$ among women. Overall, the "actual-careers" results are more in line with current data on the actual risk-of-poverty and gender gaps in poverty risks. For example, under the "full-careers" assumption, Italian women were among

Projected participation rates were taken from EPC (2009). These were adjusted to reflect the legislated increase in pension age in Germany and the UK not considered in this study.

For instance if all those aged 20 to 24 participate in labour market activity, one would be justified in assuming that individuals contribute for 5 years during this period. If the participation rate, on the other hand, is $80 \%$, the number of contribution years during this period is likelier to be 4 years. This principle is applied to all ages between 20 and pension age.

We are imposing the average labour market participation of a cross-section of generations on a single generation. Moreover we are assuming that all our individuals display average labour market participation trends over their career. These might instead differ across the wage distribution.

This is estimated by comparing the average pension wealth for the hypothetical individuals with below-median wages with the median equivalised disposable income in that country. 
the best provided for across Europe, failing to explain their high relative poverty rate (see Table 2). The "actual-careers" estimates appear to be much more representative of effective pension generosity.

Table 4: The poverty thresholds (\% of median disposable income) achievable in 2005 and 2050 under different labour market assumptions

a) Men

\begin{tabular}{|l|c|c|c|c|c|c|}
\hline \multirow{2}{*}{} & \multicolumn{3}{|c|}{ Full-careers assumption^ } & \multicolumn{3}{c|}{ Actual-careers assumption* } \\
\cline { 2 - 7 } & $\mathbf{2 0 0 5}$ & $\mathbf{2 0 5 0}$ & $\begin{array}{c}\text { Change in } \\
\text { p.p. }\end{array}$ & $\mathbf{2 0 0 5}$ & $\mathbf{2 0 5 0}$ & $\begin{array}{c}\text { Change in } \\
\text { p.p. }\end{array}$ \\
\hline Austria & 96 & 85 & -11 & 95 & 74 & -21 \\
Finland & 79 & 72 & -7 & 64 & 66 & +2 \\
France & 73 & 62 & -11 & 63 & 59 & -4 \\
Germany & 69 & 58 & -11 & 61 & 59 & -2 \\
Hungary & 79 & 82 & +3 & 70 & 65 & -5 \\
Italy & 99 & 78 & -21 & 95 & 68 & -27 \\
Poland & 77 & 54 & -23 & 66 & 50 & -16 \\
Slovakia & 102 & 77 & -25 & 93 & 51 & -42 \\
Sweden & 72 & 64 & -8 & 70 & 65 & -5 \\
UK & 48 & 61 & +13 & 46 & 59 & +13 \\
\hline
\end{tabular}

b) Women

\begin{tabular}{|l|c|c|c|c|c|c|}
\hline \multirow{2}{*}{} & \multicolumn{3}{|c|}{ Full-careers assumption^ } & \multicolumn{3}{c|}{ Actual-careers assumption* } \\
\cline { 2 - 7 } & $\mathbf{2 0 0 5}$ & $\mathbf{2 0 5 0}$ & $\begin{array}{c}\text { Change in } \\
\text { p.p. }\end{array}$ & $\mathbf{2 0 0 5}$ & $\mathbf{2 0 5 0}$ & $\begin{array}{c}\text { Change in } \\
\text { p.p. }\end{array}$ \\
\hline Austria & 69 & 70 & +1 & 68 & 61 & -7 \\
Finland & 70 & 64 & -6 & 57 & 58 & +1 \\
France & 67 & 59 & -8 & 44 & 59 & +15 \\
Germany & 55 & 52 & -3 & 48 & 56 & +8 \\
Hungary & 73 & 79 & +6 & 68 & 59 & -9 \\
Italy & 79 & 71 & -8 & 68 & 50 & -18 \\
Poland & 68 & 39 & -29 & 55 & 35 & -20 \\
Slovakia & 82 & 62 & -20 & 74 & 41 & -33 \\
Sweden & 60 & 54 & -6 & 59 & 56 & -3 \\
UK & 41 & 60 & +19 & 39 & 56 & +17 \\
\hline
\end{tabular}

${ }^{\wedge}$ These indicators are the average for the 4 hypothetical full-timer full-career workers with belowmedian wages.

* These indicators are the weighted averages for 4 hypothetical actual-careers full-timers with belowmedian wages and the hypothetical part-timer. The weights reflect the respective share of full-time and part-time workforce in each country.

Source: Own analysis using APEX. 
While these are important contributions, potentially the most interesting finding is that labour market trends can act as a countervailing force that offsets part of the effect of the pension reforms. This is particularly true in those countries where the reforms created closer links between contributions and benefits. Reforms, generally speaking, reduce the strength of the poverty alleviation function and result in a greater degree of convergence across countries. If one were to look at "full-careers", reforms make systems more generous only in the UK and in Hungary. However taking into account actual and projected labour participation shows us a different picture. Effective generosity is set to improve in some countries, like France and Germany - on account of higher labour market participation. Thus the "full-careers" estimates show women as being the main losers of the reforms, with very substantial losses anticipated, for instance, among women in Poland and Slovakia. The "actual-careers" assumption reverses this finding for some countries, as can be seen from Table 4, though it should be noted not for those countries with the strongest losses. Growing labour participation might actually result in improvements over time in pension entitlements for women despite the reforms, cases in point being France and Germany. Moreover in many countries, cuts in the general pension system's generosity have been complemented by a strengthening of minimum pensions. This has the potential to reduce the impact of the reforms on pensioner poverty.

There are similar trends when one looks at average replacement ratios - i.e. the strength of the consumption smoothing function. For instance, Table 5 shows that in Germany the average replacement ratio for men with a full career will be more than a sixth lower by 2050; and a fifth lower in Italy. The loss here is however relatively stronger and in countries like Poland, Austria and Italy the state pension on its own will not be enough to sustain pre-retirement levels of consumption. Again the decline here is much pronounced for men. Gender gaps in replacement rates should also decline, as men (with their fuller contributory records) will lose more in actual entitlements than women. This can be discerned by comparing the "full-careers" with the "actual-careers" cases - in some cases, e.g. Italy and Slovakia, the reforms favour those with full careers. However in many cases, the impact of the reforms on replacement rates differs by income; for those on high incomes generosity has been cut, while for those on low incomes it was maintained stable. In many European countries, the consumption smoothing function of the state pension system for middleto-high earners may need to be supplemented by other means. But there are notable exceptions - in Poland and Slovakia those at the bottom of the wage distribution face the toughest challenge as the system has become much less progressive. 
Table 5: The average replacement ratios through retirement (\% of preretirement wages) achievable in 2005 and 2050 under different labour market assumptions

a) Men

\begin{tabular}{|l|c|c|c|c|c|c|}
\hline & \multicolumn{3}{|c|}{ Full-careers assumption^ } & \multicolumn{3}{c|}{ Actual-careers assumption* } \\
\cline { 2 - 7 } & $\mathbf{2 0 0 5}$ & $\mathbf{2 0 5 0}$ & $\begin{array}{c}\text { Change } \\
\text { in p.p. }\end{array}$ & $\mathbf{2 0 0 5}$ & $\mathbf{2 0 5 0}$ & $\begin{array}{c}\text { Change } \\
\text { in p.p. }\end{array}$ \\
\hline Austria & 91 & 78 & -13 & 89 & 66 & -23 \\
Finland & 75 & 69 & -6 & 59 & 59 & 0 \\
France & 68 & 57 & -11 & 56 & 58 & +2 \\
Germany & 85 & 68 & -17 & 71 & 69 & -2 \\
Hungary & 85 & 90 & +5 & 74 & 62 & -12 \\
Italy & 92 & 72 & -20 & 92 & 67 & -25 \\
Poland & 87 & 63 & -24 & 67 & 56 & -11 \\
Slovakia & 72 & 67 & -5 & 62 & 56 & -6 \\
Sweden & 66 & 62 & -4 & 66 & 59 & -7 \\
UK & 40 & 48 & +8 & 37 & 53 & +16 \\
\hline
\end{tabular}

b) Women

\begin{tabular}{|l|c|c|c|c|c|c|}
\hline & \multicolumn{3}{|c|}{ Full-careers assumption^ } & \multicolumn{3}{c|}{ Actual-careers assumption* } \\
\cline { 2 - 7 } & $\mathbf{2 0 0 5}$ & $\mathbf{2 0 5 0}$ & $\begin{array}{c}\text { Change } \\
\text { in p.p. }\end{array}$ & $\mathbf{2 0 0 5}$ & $\mathbf{2 0 5 0}$ & $\begin{array}{c}\text { Change } \\
\text { in p.p. }\end{array}$ \\
\hline Austria & 83 & 82 & -1 & 75 & 66 & -9 \\
Finland & 75 & 70 & -5 & 58 & 60 & +2 \\
France & 71 & 61 & -10 & 41 & 51 & +10 \\
Germany & 82 & 71 & -11 & 59 & 67 & +8 \\
Hungary & 83 & 90 & +7 & 74 & 64 & -10 \\
Italy & 82 & 73 & -9 & 65 & 50 & -15 \\
Poland & 86 & 50 & -36 & 65 & 43 & -22 \\
Slovakia & 83 & 67 & -16 & 75 & 56 & -19 \\
Sweden & 71 & 64 & -7 & 66 & 57 & -9 \\
UK & 44 & 60 & +16 & 40 & 57 & +17 \\
\hline
\end{tabular}

$\wedge$ These indicators are the averages for the 9 hypothetical full-timer full-career workers.

* These indicators are the weighted averages for the 9 hypothetical actual-careers full-timers and the hypothetical part-timer. The weights reflect the respective share of full-time and part-time workforce in each country.

Source: Own analysis using APEX. 
Turning to pressures on constraints, our estimates suggest that had replacement ratios remained untouched by reforms, future generations of pensioners would have got much larger net pension transfers as a result of increasing longevity. The reforms appear to have addressed this. So while year-on-year replacement rates may have fallen, generally, future pensioners still get more transfers than current ones, with the exception of Italy, Poland and Slovakia. In these countries the drop is quite significant and reflects the large financial problems which these countries would have faced had they retained their previous system rules. Table 6 indicates that the consideration of labour market participation does not result in any significant reinterpretation of the development of the relative size of intergenerational pension transfers. Rising labour participation and increasing longevity should result in net pension wealth expanding slightly in many countries. Interestingly while under "full-careers", women generally lose out compared to men, on account of the equalisation of pension ages, the "actualcareers" assumption shows them in some countries, such as France and Germany, as being better off as their entitlements are buoyed by their rising labour participation (see Table 6).

Table 6: The net pension wealth of the 2050 generation compared to that of the 2005 generation under different labour market assumptions (\%)

\begin{tabular}{|l|c|c|c|c|}
\hline \multirow{2}{*}{} & \multicolumn{2}{|c|}{ Male } & \multicolumn{2}{c|}{ Female } \\
\cline { 2 - 5 } & $\begin{array}{c}\text { Full-careers } \\
\text { assumption^ }\end{array}$ & $\begin{array}{c}\text { Actual-careers } \\
\text { assumption* }\end{array}$ & $\begin{array}{c}\text { Full-careers } \\
\text { assumption^ }\end{array}$ & $\begin{array}{c}\text { Actual-careers } \\
\text { assumption* }\end{array}$ \\
\hline Austria & 109 & 94 & 98 & 87 \\
Finland & 114 & 125 & 106 & 119 \\
France & 98 & 101 & 96 & 141 \\
Germany & 92 & 104 & 95 & 124 \\
Hungary & 131 & 116 & 112 & 82 \\
Italy & 95 & 77 & 87 & 76 \\
Poland & 106 & 83 & 69 & 73 \\
Slovakia & 109 & 80 & 79 & 58 \\
Sweden & 107 & 112 & 100 & 96 \\
UK & 127 & 127 & 112 & 117 \\
\hline
\end{tabular}

$\wedge$ These indicators are the averages for the 9 hypothetical full-timer full-career workers.

* These indicators are the weighted averages for the 9 hypothetical actual-careers full-timers and the hypothetical part-timer. The weights reflect the share of full- and part-time workforce in each country. Source: Own analysis using APEX.

In Table 7 we present estimates of the contribution rates workers in 2005 and 2050 would need to pay to finance the pension transfers to the pensioner cohorts retiring in those years. For 2050, the financing cost is presented both for the reformed pension systems and also assuming no reforms had taken place (so that system rules remained as at 2005). Table 7 suggests that while generosity is smaller under the "actual careers" assumption, the financing requirements of pension systems are significantly higher under the actual-careers assumption. On average, across Europe a contribution rate of $17 \%$ is required to finance the pension wealth of the currently retired as against 
the $11 \%$ implied when modelling full-careers. Moreover in the absence of reforms, fiscal pressures would have increased substantially more. The impact of the ageing transition, in fact, would be compounded by the impact of increasing women's entitlement to pensions. The reforms, however, partially address this factor so that the increase in fiscal pressures by 2050 is of around 10 percentage points, on average. There are some notable outliers, however, such as France, Poland and Slovakia, where the required increase is around double this increase. In these countries, weak labour market participation combines with rapid ageing to make up a very dangerous cocktail. The trends implied by the estimates in Table 7 differ from standard assessments of pension spending projections, as they suggest that despite reforms the financing burden of pension systems will still increase very significantly (by contrast, EPC (2009) suggests pension spending across the EU will rise by just 2.4\% of GDP by 2060). This is because our measure captures better the full implications of longevity increases, by looking at pension spending for the whole retirement period of a cohort, rather than focusing on one year of future spending.

\section{Table 7: Comparing financial sustainability under the different careers assumptions*}

\begin{tabular}{|l|c|c|c|c|c|c|}
\hline \multirow{2}{*}{} & \multicolumn{3}{|c|}{ Full-careers assumption } & \multicolumn{3}{c|}{ Actual-careers assumption } \\
\cline { 2 - 7 } & $\mathbf{2 0 0 5}$ & $\begin{array}{c}\text { Pre-reform } \\
\mathbf{2 0 5 0}\end{array}$ & $\begin{array}{c}\text { Post-reform } \\
\mathbf{2 0 5 0}\end{array}$ & $\mathbf{2 0 0 5}$ & $\begin{array}{c}\text { Pre-reform } \\
\mathbf{2 0 5 0}\end{array}$ & $\begin{array}{c}\text { Post-reform } \\
\mathbf{2 0 5 0}\end{array}$ \\
\hline Austria & 13.8 & 27.3 & 22.7 & 19.3 & 47.7 & 26.8 \\
Finland & 8.5 & 20.4 & 18.3 & 8.7 & 23.7 & 20.9 \\
France & 14.6 & 29.6 & 24.3 & 21.0 & 50.3 & 41.4 \\
Germany & 8.0 & 17.9 & 14.4 & 11.8 & 39.6 & 20.9 \\
Hungary & 22.0 & 43.0 & 30.8 & 37.7 & 80.9 & 44.5 \\
Italy & 17.3 & 34.1 & 24.7 & 29.7 & 67.1 & 31.6 \\
Poland & 8.4 & 30.4 & 20.7 & 14.4 & 67.7 & 34.7 \\
Slovakia & 11.1 & 35.9 & 24.6 & 20.6 & 85.4 & 38.7 \\
Sweden & 10.1 & 18.3 & 16.7 & 11.5 & 30.4 & 21.5 \\
UK & 5.8 & 7.1 & 6.7 & 9.1 & 17.6 & 10.3 \\
\hline Average^ & 11.1 & 23.6 & 18.3 & 17.5 & 47.2 & 27.2 \\
\hline
\end{tabular}

* The proportion of total lifetime wages needed to finance the pension wealth of different generations.

$\wedge$ The contribution rate of a country is weighted in line with relative population size.

Source: Own estimates using APEX, EU labour market and population projections.

\section{Overall assessment of social sustainability of pension reforms}

The achievement of "sustainability" has been the main objective that policymakers have set themselves when reforming pension systems. While this paper acknowledges, and its findings confirm, the importance of achieving long-term sustainability of pension systems given the significant challenges they face, it has argued that policymakers need to adopt a more comprehensive definition of sustainability. When looking into the future, policymakers need to reassure themselves not only that 
pressure on constraints is being managed properly, but also that the pension system remains effective and is in a position to achieve the goals it is expected to. To do this, policymakers need to be able to map out the impact of reforms on the strength of the poverty alleviation and consumption smoothing functions, particularly for groups with low incomes and/or partial careers, together with the influence reforms have on relative size of transfers between generations, both in terms of the net pension wealth accruing to future generations and the contribution rates required to finance these transfers.

Figures 4 and 5 present an example of how this mapping out can be made. They compare how the achievement of the twin goals of pension systems and the pressure on system constraints should change by 2050 when looking across the aggregate pensioner population. This approach allows one to understand whether one aim is being sacrificed for better results on the other, and provides an indication of how the role and scope of state pension systems will evolve. The fact that this comparison is done on a cross-country basis also allows one to understand how different policymakers reacted to similar challenges. There are some quite striking similarities. For instance, only countries which faced a very substantial fiscal challenge due to ageing put in place reforms that cut the relative size of total pension transfers to future generations. In most countries, the reforms offset only part of the effect on pension wealth of the projected rise in longevity, and accommodate the projected change in the relative size in the pensioner population by a rising (implied) contribution rate.

\section{Figure 4: The development of system achievements}

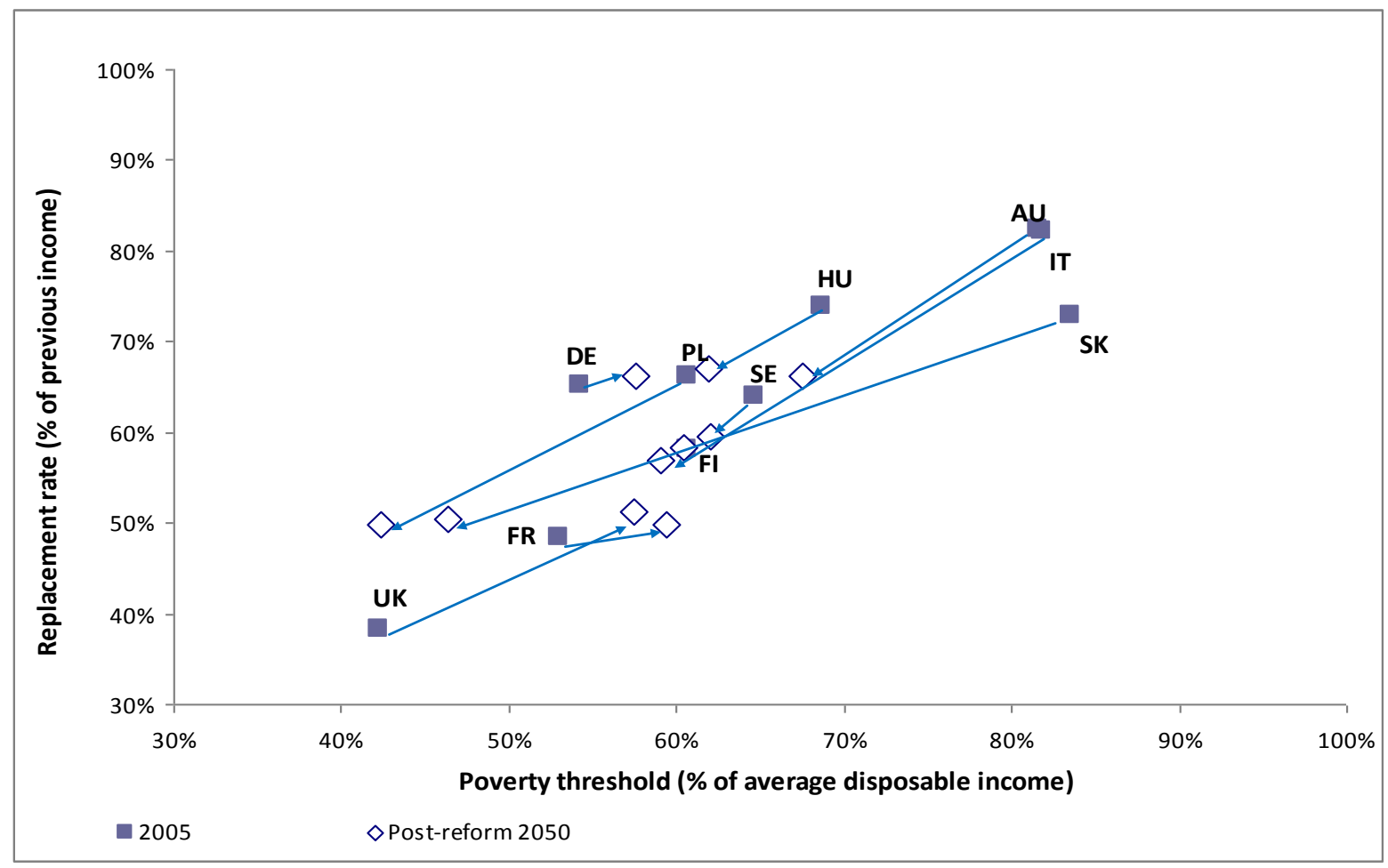

Note: The indicators presented show the poverty threshold (as a \% of the national median disposable wage) that could be achieved, on average, throughout retirement by our estimates of the average net pension wealth of our 4 hypothetical individuals of each gender with below-median wages in each country. They also show the replacement rate ( $\%$ of the individuals' pre-retirement wage) that could 
be achieved, on average, throughout retirement by our estimates of the average net pension wealth of our 9 hypothetical full-time workers and our part-time worker of each gender (weighted in line with the share of full-time and part-time employment in that country).

Figure 5: The development of system constraints

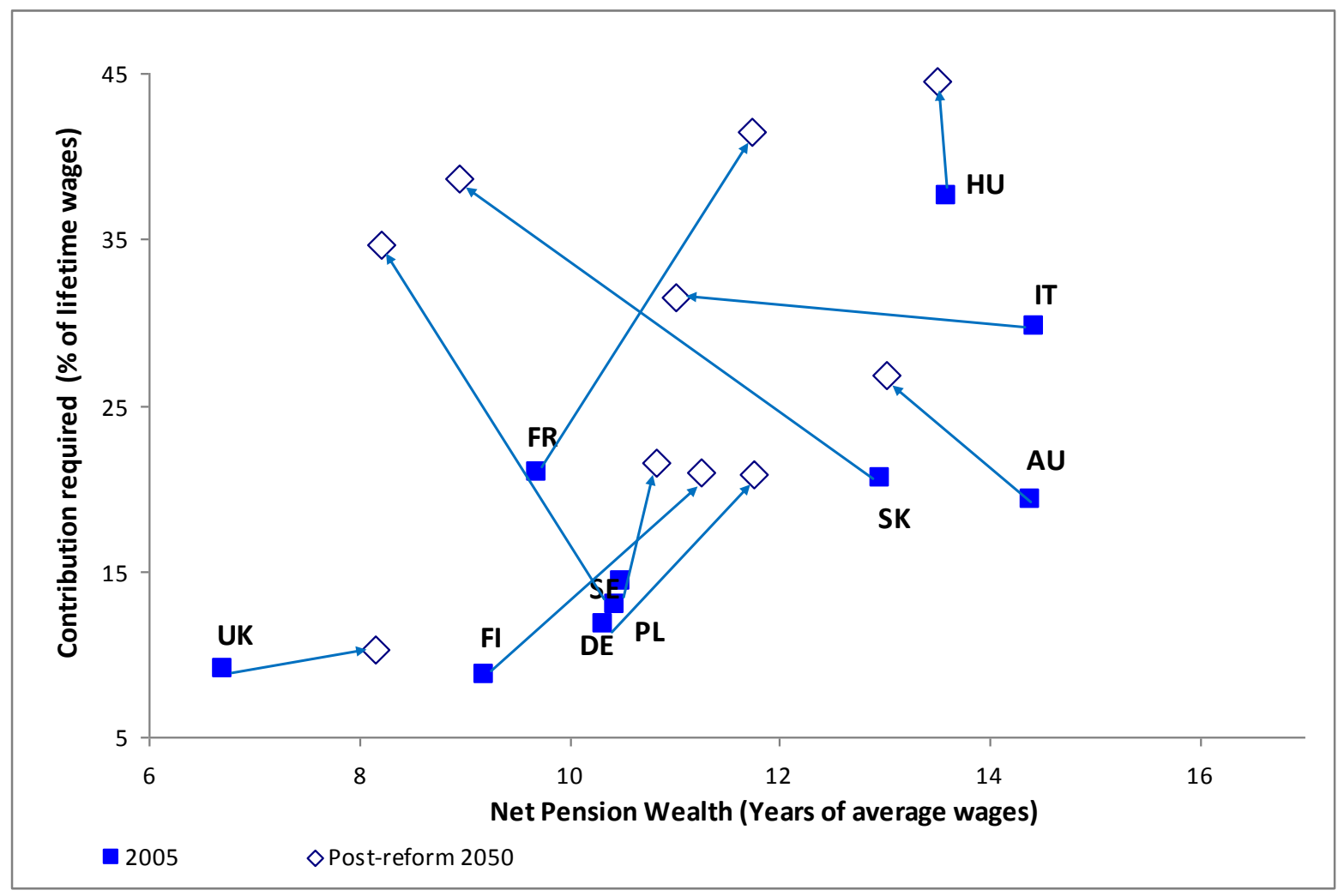

Note: The indicators presented show the average net pension wealth (in terms of the contemporary average wage) of our 9 hypothetical full-time workers and our part-time worker of each gender (weighted in line with the share of full-time and part-time employment in that country).They also show the contribution rate ( $\%$ of lifetime wages) required to finance this average net pension wealth given the ratio of pension beneficiaries to contributors.

Figure 4 points out how most countries will converge towards providing pension wealth which keeps individuals above the $60 \%$ poverty threshold throughout retirement. The only exceptions appear to be Poland and Slovakia. Despite these radical cuts, these countries will still experience large increases in their financing costs (see Figure 5), on account of steeply declining support ratios. Improving employment rates could help stem these developments. In a similar vein, in France the system seems to face significant fiscal challenges, which could be partially addressed by increasing employment at older ages and raising the state pension age - two options which the French government is looking at. ${ }^{18}$

The above analysis can be deepened by looking more closely at the social sustainability indicators, and zooming to particular sections of the population. For instance, Figure 6 compares the gender and income distribution effects of pension 
reforms in Poland and the UK. This shows very clearly that the impact of the pension reforms in Poland will be more strongly felt by those on low incomes, and particularly women. By contrast in the UK, the effects of reforms are clearly very progressive. Our social sustainability indicators help set out the major risks faced by pension systems. They show that in some countries, like Poland and Slovakia, pensioner poverty could become an issue, while in others future pensioner generations may be seen to be favoured at the expense of current pensioner generations (e.g. Finland, UK) and/or future generations of workers (e.g. France). At the same time, it is important to stress that these considerations are valid only if the assumptions on future employment growth and longevity prove correct. In some countries, the assessment would be very different if working careers remained unchanged (particularly among women) - e.g. poverty risks in Germany and Italy would be higher - or if longevity were to improve at a faster pace - e.g. the contribution rate in France and Hungary would need to rise by substantially more.

Figure 6: Net pension wealth of the 2050 generation compared to the 2005 generation for the 11 hypothetical cases

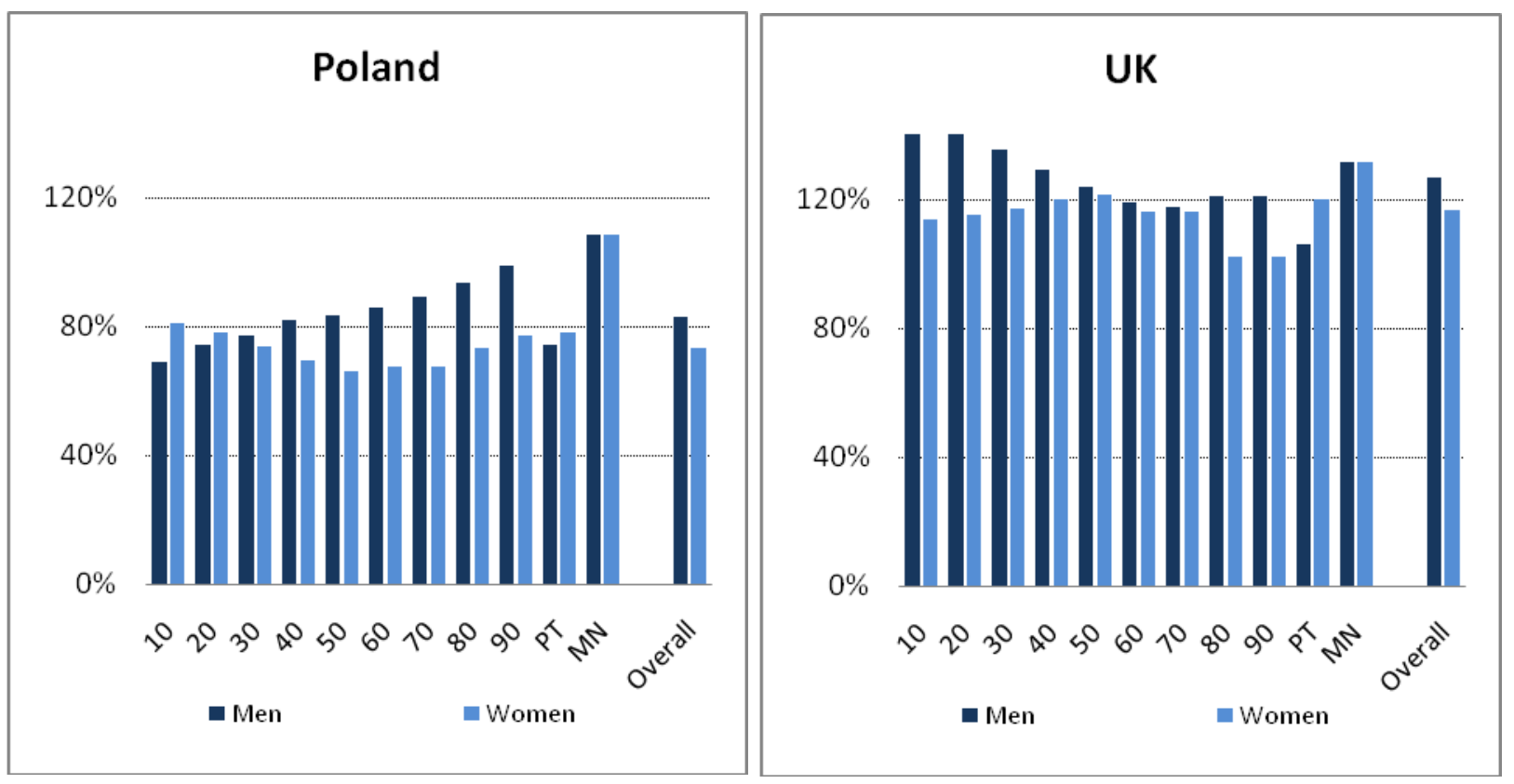

In Figure 7, we return to the taxonomy depicted in Figure 2 and attempt to show how the composition of the different pension system categories might change by 2050 as a result of reforms. However it should be kept in mind that the overall situation in 2050 will be very different from that in 2005 , as can be inferred from the averages for the four indicators shown in Figures 4 and 5. In particular, the level of pension spending, on average, will be significantly higher, there will be more convergence across countries in terms of replacement rates and the risk-of-poverty among pensioners could be higher than in Figure 2.

The estimated changes in the social sustainability indicators suggest that while there will still be three general groups of countries (Group A - systems with high levels of income replacement and low pensioner poverty, but high spending, Group B systems with high or low spending, but low replacement rates and high pensioner 
poverty, and Group $\mathrm{C}$ - systems with low spending, low replacement rates and low pensioner poverty); the composition of the groups could change significantly. For instance, Poland and Slovakia could go to join Italy in Group B, as their level of pensioner poverty could be negatively affected by the pension reforms they have put in place, while at the same time the lack of labour participation combined with ageing will result in a substantial increase in their pension financing cost. Group B will, however, probably lose one member, the UK. By focusing resources even more on those on low incomes and women, the UK pension system should make inroads on pensioner poverty while maintaining spending low on account of the planned increase in pension ages. The UK could join the Scandinavian duo, Finland and Sweden, but their level of pension spending will increase, rising to levels which in 2005 characterised high-spending countries. In Group A, besides the movement of Poland, Hungary could be moving towards Group B, as the reforms leave some groups at-riskof-poverty.

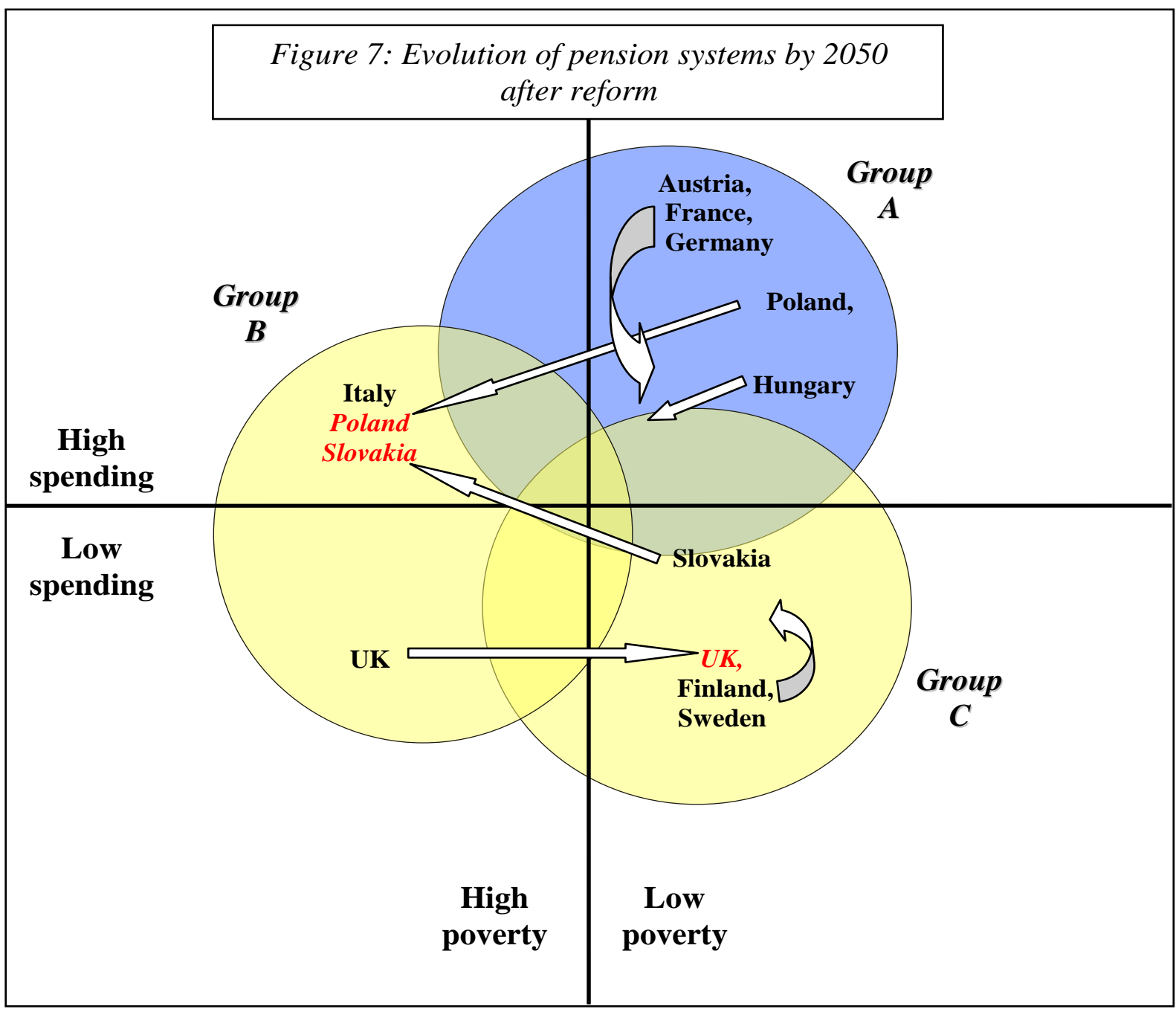

Note: Groups B and C are both shaded lightly, as countries classified in these groups have low replacement rates; while those in Group A have high replacement rates. Countries placed above the horizontal line are high spenders on state pensions. Countries placed to the left of the vertical line have higher-than-average elderly poverty. The position of the countries in these groups reflects the extent to which their level of pension spending, relative income of the elderly and percentage of elderly population at risk-of-poverty differs from the EU average. Countries which are expected move categories as a result of the reforms are shown in italics. The arrows show the direction of movement of the country's pension system along the three dimensions studied. 
The position of Austria, Germany and France may also change, as they move closer to Group $\mathrm{C}$ in terms of the replacement rates they provide. One could argue that France will separate from the other two, as it faces much higher projected increases in spending, and join Hungary, but at the same time the French system appears to have a much more effective poverty alleviation function than the Hungarian one. The only country that might still be in the same place it occupies today is Italy. While the reforms mean that it will be less of an outlier in spending terms, low labour participation among older workers and women, together with lack of pension protection for the unemployed could keep pensioner poverty levels high while the reforms have cut the replacement rates individuals can look forward to in 2050.

\section{Policy considerations}

After having applied our social sustainability assessment framework empirically, we can now proceed to make some policy considerations. Two questions appear to be particularly relevant in this respect - namely the possibility that changes in individual economic behaviour could accommodate changes in pension generosity; and the resilience of pension systems to shocks.

Policymakers have tended to argue that any negative impacts of pension reforms on retirement income can be undone by means of additional private saving. While this may be feasible for those on medium- to high-incomes, this is less likely for those with low-incomes. In Table 8 we show that in many countries these individuals would need to save relatively high amounts in order to generate the same average replacement rates throughout retirement as in 2005, even if they accept the reduction in pension wealth due to higher pension ages. Moreover, notably in Poland and Slovakia, this task is made more difficult by the fact that individuals will also be called upon to pay higher contribution rates to pay for contemporary pension transfers. 
Table 8: Additional saving (\% of wages) to maintain consumption smoothing (actual-careers case) unchanged between 2005 and 2050 (assumed net nominal rate of return: $5.5 \%$ )

a) Men

\begin{tabular}{|l|c|c|c|c|c|c|c|c|c|c|}
\hline & $\begin{array}{c}\text { 10th } \\
\text { Decile }\end{array}$ & $\begin{array}{c}\text { 20th } \\
\text { Decile }\end{array}$ & $\begin{array}{c}\text { 30th } \\
\text { Decile }\end{array}$ & $\begin{array}{c}\text { 40th } \\
\text { Decile }\end{array}$ & $\begin{array}{c}\text { 50th } \\
\text { Decile }\end{array}$ & $\begin{array}{c}\text { 60th } \\
\text { Decile }\end{array}$ & $\begin{array}{c}\text { 70th } \\
\text { Decile }\end{array}$ & $\begin{array}{c}\text { 80th } \\
\text { Decile }\end{array}$ & $\begin{array}{c}\text { 90th } \\
\text { Decile }\end{array}$ & $\begin{array}{c}\text { Part- } \\
\text { time }\end{array}$ \\
\hline Austria & 7.6 & 7.6 & 7.6 & 7.5 & 7.7 & 8.0 & 8.5 & 9.2 & 8.0 & 8.7 \\
Finland & & & & & & & & & & \\
France & & & 2.6 & 4.8 & 4.8 & 4.6 & 5.1 & 4.7 & 4.0 & 5.1 \\
Germany & & 0.6 & 0.8 & 1.1 & 1.4 & 1.8 & 2.3 & 3.0 & 4.0 & 1.4 \\
Hungary & 0.4 & 0.4 & 0.4 & 0.4 & 0.4 & 0.3 & & & & \\
Italy & 13.3 & 13.4 & 13.5 & 13.5 & 13.7 & 13.9 & 13.9 & 13.6 & 13.2 & 13.6 \\
Poland & 8.9 & 7.2 & 6.3 & 4.7 & 4.3 & 3.7 & 2.8 & 1.8 & 0.6 & 6.4 \\
Slovakia & 12.6 & 12.9 & 13.1 & 13 & 11.5 & 7.5 & 3.6 & & & 12.9 \\
Sweden & 3.4 & 2.1 & 2.2 & 2.4 & 2.5 & 2.6 & 2.7 & & & \\
UK & & & & & & & & & & \\
\hline
\end{tabular}

b) Women

\begin{tabular}{|l|c|c|c|c|c|c|c|c|c|c|}
\hline & $\begin{array}{c}\text { 10th } \\
\text { Decile }\end{array}$ & $\begin{array}{c}\text { 20th } \\
\text { Decile }\end{array}$ & $\begin{array}{c}\text { 30th } \\
\text { Decile }\end{array}$ & $\begin{array}{c}\text { 40th } \\
\text { Decile }\end{array}$ & $\begin{array}{c}\text { 50th } \\
\text { Decile }\end{array}$ & $\begin{array}{c}\text { 60th } \\
\text { Decile }\end{array}$ & $\begin{array}{c}\text { 70th } \\
\text { Decile }\end{array}$ & $\begin{array}{c}\text { 80th } \\
\text { Decile }\end{array}$ & $\begin{array}{c}\text { 90th } \\
\text { Decile }\end{array}$ & $\begin{array}{c}\text { Part- } \\
\text { time }\end{array}$ \\
\hline Austria & 2.2 & 3.8 & 4.0 & 3.2 & 3.0 & 3.0 & 3.0 & 3.1 & 3.8 & 3.3 \\
Finland & & & & & & & & & & \\
France & & & & & & & & & & \\
Germany & & & & & & & & 0.2 & 1.0 & \\
Hungary & 7.8 & 5.3 & 6.8 & 5.6 & 5.8 & 6.0 & 6.3 & 5.9 & 5.6 & 6.0 \\
Italy & 6.3 & 5.2 & 6.2 & 5.8 & 5.8 & 5.8 & 5.8 & 6.3 & 6.4 & 5.8 \\
Poland & 15.4 & 14.6 & 13 & 12.5 & 11.9 & 11 & 9.7 & 8.3 & 6.7 & 12.6 \\
Slovakia & 17.7 & 18.2 & 18.5 & 18.7 & 18.9 & 18.9 & 19.0 & 16.3 & 6.6 & 18.7 \\
Sweden & 5.0 & 5.1 & 4.4 & 3.1 & 3.3 & 3.5 & 3.7 & 4.0 & 0.7 & 3.9 \\
UK & & & & & & & & & & \\
\hline
\end{tabular}

Note: In cases where consumption smoothing will be higher in 2050, no estimates are made. Source: Own workings using APEX.

Longer working lives present a more likely way of maintaining consumption smoothing. Table 9 presents estimates of the change in replacement rates, on average, under different career lengths. This confirms that reforms place a significant disincentive for individuals to maintain the same career length as in 2005. By contrast, longer careers undo a significant part of the reduction in generosity, except in countries with very high replacement rates. In the latter cases, policymakers appear to have concentrated on reducing costs. 
Table 9: The overall replacement ratio (\% of pre-retirement wage) achievable in 2005 and change by 2050 under different labour market assumptions*

a) $\mathrm{Men}^{\wedge}$

\begin{tabular}{|l|c|c|c|c|c|c|}
\hline & $\begin{array}{c}\mathbf{2 0 0 5} \\
(\%)\end{array}$ & $\begin{array}{c}\text { Change by } \\
\mathbf{2 0 5 0} \text { under } \\
\mathbf{2 0 0 5} \text { career }\end{array}$ & $\begin{array}{c}\text { Change by } \\
\mathbf{2 0 5 0} \text { under } \\
\text { assumed } \\
\text { career }\end{array}$ & $\begin{array}{c}\text { Change by } \\
\mathbf{2 0 5 0} \text { if } \\
\text { career is 1 } \\
\text { year more }\end{array}$ & $\begin{array}{c}\text { Change by } \\
\mathbf{2 0 5 0} \text { if } \\
\text { career is 3 } \\
\text { years more }\end{array}$ & $\begin{array}{c}\text { Change by } \\
\mathbf{2 0 5 0} \text { if } \\
\text { career is } 5 \\
\text { years more }\end{array}$ \\
\hline Austria & 89 & -27 & -23 & -22 & -20 & -18 \\
Finland & 59 & -4 & 0 & +1 & +2 & +3 \\
France & 56 & -2 & +2 & +3 & +7 & +8 \\
Germany & 71 & -3 & -2 & -1 & +1 & +3 \\
Hungary & 74 & -16 & -12 & -11 & -6 & -3 \\
Italy & 92 & -27 & -25 & -24 & -22 & -22 \\
Poland & 67 & -15 & -11 & -10 & -8 & -7 \\
Slovakia & 62 & -9 & -6 & -5 & -3 & -2 \\
Sweden & 66 & -9 & -7 & -4 & +1 & +6 \\
UK & 37 & +15 & +16 & +16 & +17 & +17 \\
\hline
\end{tabular}

b) Women^

\begin{tabular}{|l|c|c|c|c|c|c|}
\hline & $\begin{array}{c}\text { 2005 } \\
(\%)\end{array}$ & $\begin{array}{c}\text { Change by } \\
\mathbf{2 0 5 0} \text { under } \\
\text { 2005 career }\end{array}$ & $\begin{array}{c}\text { Change by } \\
\mathbf{2 0 5 0} \text { under } \\
\text { assumed } \\
\text { career }\end{array}$ & $\begin{array}{c}\text { Change by } \\
\mathbf{2 0 5 0} \text { if } \\
\text { career is 1 } \\
\text { year more }\end{array}$ & $\begin{array}{c}\text { Change by } \\
\mathbf{2 0 5 0} \text { if } \\
\text { career is 3 } \\
\text { years more }\end{array}$ & $\begin{array}{c}\text { Change by } \\
\mathbf{2 0 5 0} \text { if } \\
\text { career is 5 } \\
\text { years more }\end{array}$ \\
\hline Austria & 75 & -16 & -9 & -8 & -6 & -3 \\
Finland & 58 & -6 & +2 & +2 & +1 & +2 \\
France & 41 & +7 & +10 & +10 & +12 & +15 \\
Germany & 59 & +7 & +8 & +9 & +11 & +13 \\
Hungary & 74 & -19 & -10 & -9 & -5 & -4 \\
Italy & 65 & -21 & -15 & -14 & -13 & -10 \\
Poland & 65 & -26 & -22 & -21 & -21 & -20 \\
Slovakia & 75 & -23 & -19 & -18 & -15 & -14 \\
Sweden & 66 & -17 & -9 & -7 & -2 & +2 \\
UK & 40 & +14 & +17 & +17 & +19 & +19 \\
\hline
\end{tabular}

* This represents the replacement rate (defined in terms of pre-retirement income) throughout retirement which net pension wealth at pension age could finance.

$\wedge$ These indicators are the weighted averages for the 9 hypothetical actual-careers full-timers and the hypothetical part-timer. The weights reflect the share of full-time and part-time work in each country. Source: Own analysis using APEX.

Labour market participation also plays a large part in ensuring the resilience of pension systems to shocks. Different longevity assumptions have significant impacts on the sustainability indicators, particularly for those countries which have not adopted features in their pension systems which automatically take into account 
improvements in life expectancy. Longevity increases the length of retirement, and tends to reduce overall generosity as pensions in payment tend to lose value relative to average earnings over time. The resilience of the poverty alleviation function to higher longevity is very dependent on the generosity of minimum pensions (e.g. pensioners in Sweden and Italy are better protected than those in Poland), while that of consumption smoothing is linked to the length of working lives, particularly in systems which have linked closer contributions and benefits.

As for the pressure on constraints, longevity shocks inevitably result in stronger impacts, though the UK with its relatively modest and increasingly flat pension system is also not that much affected by higher longevity. The Hungarian system is the one that appears least resilient (see Figure 8). By contrast the French system appears to be one of the systems which would gain the most if working lives rise, with each additional year cutting the required increase in contribution rates by nearly one percentage point. In countries like Sweden, Germany, and France the fiscal impact of a two-year rise in longevity can be offset by a three-year increase in working lives, while in others, such as Hungary, Italy, and Slovakia a six-year increase would suffice.

Figure 8: Change in contribution rate (\% of total lifetime wages) required to finance pension transfers implied by different longevity and labour market participation assumptions

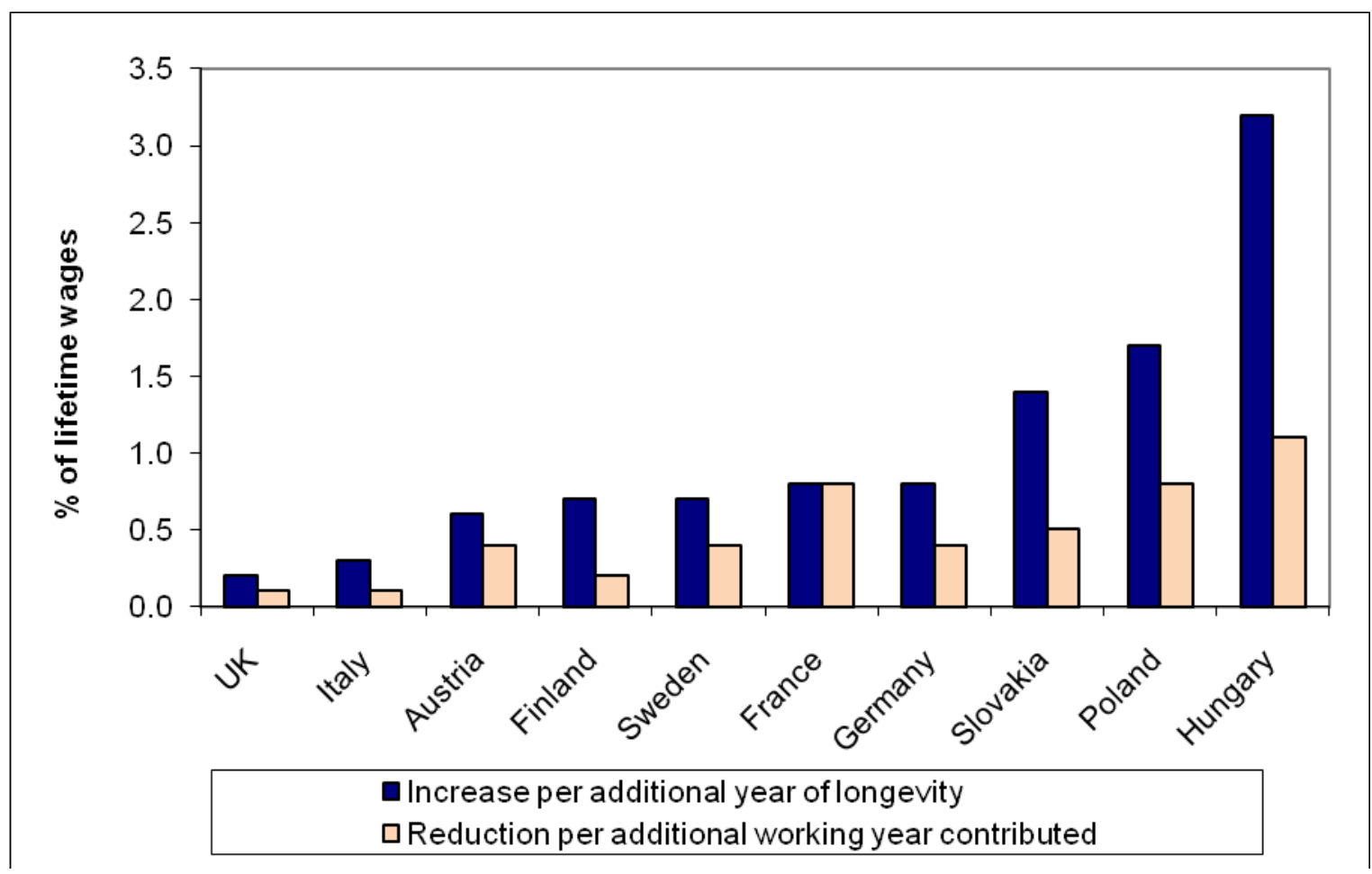

In light of the analysis made in this section, Table 10 provides a final overview of the reforms and the remaining issues that policymakers in these countries need to address. In some countries, e.g. France, the crucial first step is to address the financial sustainability of the system, by increasing the effective retirement age. In others, e.g. Poland, the emphasis could be on providing better safety nets, particularly for women. 
In others, e.g. the UK and Italy, policymakers should attempt to entrench for the longterm the principles introduced by recent reforms.

Table 10: Overview of the reforms and remaining issues

\begin{tabular}{|c|c|c|c|}
\hline & System aims & System constraints & Policy options \\
\hline Austria & $\begin{array}{l}\text { Generosity cut but system } \\
\text { remains quite adequate } \\
\text { and gender outcomes } \\
\text { more equal; those on high } \\
\text { incomes require private } \\
\text { saving to achieve } \\
\text { previous } \\
\text { smoothing. }\end{array}$ & $\begin{array}{l}\text { Reformed system reduces } \\
\text { slightly future pension } \\
\text { wealth, but contribution } \\
\text { rate still needs to rise. }\end{array}$ & $\begin{array}{l}\text { There may be scope for } \\
\text { further reductions in } \\
\text { system generosity for } \\
\text { high earners but at the } \\
\text { same time try to raise } \\
\text { labour participation } \\
\text { among those aged 50+. }\end{array}$ \\
\hline Finland & $\begin{array}{l}\text { Achievement of system } \\
\text { aims to improve slightly; } \\
\text { but very high penalties } \\
\text { for periods spent } \\
\text { unemployed, minimum } \\
\text { pensions relatively low. }\end{array}$ & $\begin{array}{l}\text { Very substantial rise in } \\
\text { required contribution rate } \\
\text { reflecting the fact that } \\
\text { pension wealth to } \\
\text { increase at same time that } \\
\text { number of pensioners will } \\
\text { rise. }\end{array}$ & $\begin{array}{l}\text { Need to extend working } \\
\text { lives so that effective } \\
\text { retirement age rises; } \\
\text { provide a better safety net } \\
\text { for those on low incomes } \\
\text { and unemployment } \\
\text { credits; private saving } \\
\text { needs to provide the } \\
\text { income smoothing that } \\
\text { state system does not } \\
\text { allow. }\end{array}$ \\
\hline France & $\begin{array}{l}\text { Better poverty alleviation } \\
\text { because of higher } \\
\text { minimum pensions and } \\
\text { credits for childcare and } \\
\text { unemployment; but drop } \\
\text { in previous income } \\
\text { smoothing through state } \\
\text { alone. }\end{array}$ & $\begin{array}{l}\text { Very strong rise in } \\
\text { required contribution rate, } \\
\text { with net pension wealth } \\
\text { rising notably on account } \\
\text { of longevity rise. }\end{array}$ & $\begin{array}{l}\text { Employment rates among } \\
\text { the over } 50 \text { and women } \\
\text { are an issue; raise pension } \\
\text { age to induce longer } \\
\text { working lives; need to } \\
\text { sustain state system with } \\
\text { private saving. }\end{array}$ \\
\hline Germany & $\begin{array}{l}\text { Reform makes system } \\
\text { more progressive and } \\
\text { makes gender outcomes } \\
\text { more equal. }\end{array}$ & $\begin{array}{l}\text { Women set to receive } \\
\text { much higher pension } \\
\text { wealth, and together with } \\
\text { ageing this will raise } \\
\text { fiscal cost of the system } \\
\text { significantly. }\end{array}$ & $\begin{array}{l}\text { Income smoothing may } \\
\text { require more private } \\
\text { saving; need to extend } \\
\text { working lives beyond age } \\
60 .\end{array}$ \\
\hline
\end{tabular}


Table 10: Overview of the reforms and remaining issues..cont..

\begin{tabular}{|c|c|c|c|}
\hline & System aims & System constraints & Policy options \\
\hline Hungary & $\begin{array}{l}\text { Reforms have made a } \\
\text { generous system even } \\
\text { more generous for those } \\
\text { on high incomes while } \\
\text { provision for women and } \\
\text { those on low incomes } \\
\text { seems lacking, } \\
\text { particularly in terms of } \\
\text { contribution credits. }\end{array}$ & $\begin{array}{l}\text { The pension system faces } \\
\text { a very substantial fiscal } \\
\text { challenge; while pension } \\
\text { wealth remains stable } \\
\text { despite state pension age } \\
\text { rise. Note however that a } \\
2009 / 10 \text { IMF-inspired } \\
\text { pension reform may have } \\
\text { helped to address this } \\
\text { financing problem. }\end{array}$ & $\begin{array}{l}\text { Make the system more } \\
\text { progressive and cut } \\
\text { generosity for those on } \\
\text { high incomes while } \\
\text { redirecting spending to } \\
\text { provide better pensions } \\
\text { for women and those on } \\
\text { low incomes; introduce } \\
\text { automatic adjustments so } \\
\text { that longevity shocks do } \\
\text { not overburden the } \\
\text { system; employment rates } \\
\text { among those aged 50+ } \\
\text { are very low. }\end{array}$ \\
\hline Italy & $\begin{array}{l}\text { Reform has decreased } \\
\text { generosity substantially } \\
\text { and could result in a } \\
\text { significant rise in poverty } \\
\text { among women; } \\
\text { unemployment carries a } \\
\text { very heavy price in } \\
\text { pension terms. }\end{array}$ & $\begin{array}{l}\text { Pension system quite } \\
\text { expensive at present, but } \\
\text { reform reduces future } \\
\text { rises in contribution rates } \\
\text { by decreasing pension } \\
\text { wealth very significantly } \\
\text { for future pensioners. }\end{array}$ & $\begin{array}{l}\text { Employment among the } \\
\text { young, 50+ and women } \\
\text { very low and if increased } \\
\text { would help address } \\
\text { financial cost; adequate } \\
\text { consumption smoothing } \\
\text { requires private saving; } \\
\text { provide better protection } \\
\text { for unemployment and } \\
\text { improve outcomes for } \\
\text { those on low incomes, } \\
\text { possibly by making } \\
\text { system progressive; make } \\
\text { sure automatic } \\
\text { adjustments are enforced. }\end{array}$ \\
\hline Poland & $\begin{array}{l}\text { Reform has reduced } \\
\text { significantly system's } \\
\text { progressiveness and there } \\
\text { are serious poverty } \\
\text { concerns for women and } \\
\text { those on low incomes; } \\
\text { very little protection for } \\
\text { women with children and } \\
\text { the unemployed. }\end{array}$ & $\begin{array}{l}\text { System faces a very } \\
\text { substantial } \\
\text { challenge, even though } \\
\text { future net pension wealth } \\
\text { has been reduced. }\end{array}$ & $\begin{array}{l}\text { Employment among the } \\
\text { young, 50+ and women } \\
\text { very low and if increased } \\
\text { would reduce costs and } \\
\text { improve adequacy; low } \\
\text { pension age for women } \\
\text { combined with NDC } \\
\text { system makes them worse } \\
\text { off - pension age should } \\
\text { be equal; need to improve } \\
\text { minimum pensions and } \\
\text { provide contribution } \\
\text { credits: financed by } \\
\text { cutting pensions for those } \\
\text { on high incomes. }\end{array}$ \\
\hline
\end{tabular}


Table 10: Overview of the reforms and remaining issues..cont..

\begin{tabular}{|c|c|c|c|}
\hline & System aims & System constraints & Policy options \\
\hline Slovakia & $\begin{array}{l}\text { Reform has reduced } \\
\text { significantly system's } \\
\text { progressiveness and there } \\
\text { are serious poverty } \\
\text { concerns for women and } \\
\text { those on low incomes, } \\
\text { unless labour } \\
\text { participation rises in } \\
\text { older ages. }\end{array}$ & $\begin{array}{l}\text { Reform has reduced the } \\
\text { required increase in } \\
\text { contribution rates, but } \\
\text { system still faces big rise. } \\
\text { Pension wealth cut for } \\
\text { future generations, } \\
\text { particularly women and } \\
\text { those on low incomes. }\end{array}$ & $\begin{array}{l}\text { Increase labour } \\
\text { participation among those } \\
\text { aged 50+, revisit the } \\
\text { extent of cuts made for } \\
\text { those on lower incomes - } \\
\text { by providing better } \\
\text { minimum pensions } \\
\text { and/or credits for periods } \\
\text { spent unemployed. }\end{array}$ \\
\hline Sweden & $\begin{array}{l}\text { Post-reform system aims } \\
\text { achievement remains } \\
\text { adequate but this is now } \\
\text { more dependent on } \\
\text { extending working lives, } \\
\text { some concern for those } \\
\text { dependent on minimum } \\
\text { pension - uprated by } \\
\text { prices. }\end{array}$ & $\begin{array}{l}\text { Achieves good degree of } \\
\text { intergenerational balance; } \\
\text { limits fiscal pressure by } \\
\text { cutting benefits if people } \\
\text { retire at same age. }\end{array}$ & $\begin{array}{l}\text { Continue to support the } \\
\text { pension system with an } \\
\text { active labour market } \\
\text { policy; ensure individuals } \\
\text { are aware of the need of } \\
\text { working longer, earnings } \\
\text { uprate the minimum } \\
\text { pension; supplement state } \\
\text { system with private } \\
\text { saving to achieve better } \\
\text { income smoothing. }\end{array}$ \\
\hline UK & $\begin{array}{l}\text { Improvements in pension } \\
\text { alleviation function - } \\
\text { particularly among } \\
\text { women; state system on } \\
\text { its own, however, is just } \\
\text { a foundation for adequate } \\
\text { retirement provision. }\end{array}$ & $\begin{array}{l}\text { Financial pressure } \\
\text { relatively low, on account } \\
\text { of rising pension age }\end{array}$ & $\begin{array}{l}\text { Ensure private pensions } \\
\text { fulfill income smoothing } \\
\text { role; reduce reliance on } \\
\text { means-tested benefits - } \\
\text { where non take-up could } \\
\text { reduce effectiveness of } \\
\text { poverty alleviation; } \\
\text { ensure pension age policy } \\
\text { remains linked to } \\
\text { longevity. }\end{array}$ \\
\hline
\end{tabular}

\section{Conclusion}

The main analytical contribution of the above analysis is the holistic and internally consistent way in which reforms are evaluated. By looking at the various elements together, it is easier to understand the trade-offs which can be exploited and the risks that particular policies may pose. While most literature has focused solely on how best pension systems can face the challenge posed by the ageing transition, this analysis has refocused the discussion on the really central question - what do pension systems achieve and at what cost. Just looking at one part of the phrase - 'at what cost' - is counterintuitive. Rather policymakers need to focus on what realistically systems can achieve, and act in a way as to change individual behaviour so that any changes in public provision are accommodated by private actions. 
The social sustainability framework proposed in this paper allows the analysis of various other questions and can be used to generate a lot of in-depth analysis of the consequences of reforms on different individuals. The framework lends itself to being used across different pension regimes and enables comparison of reforms which are very different in nature. It can also be used to see how systems are changing and the extent of convergence in system goals and pressure on constraints. This multi-faceted framework is not however to be conceived as some form of benchmarking exercise. Rather its main aim is to capture as much as possible the full implications of reforms in order to arrive at some understanding of the potential pressures policymakers could face in the future, and help map the tactical and strategic decisions which policymakers have taken or need to take to achieve long-term stability in this field.

This assessment framework also clearly puts longevity at the centre of analysis. In spite of being the main long-term determinant of the size of pension transfers, longevity has tended to be ignored in most existing literature assessing pension reforms. By concentrating on point-in-time indicators like prospective theoretical replacement rates at retirement and spending as a percentage of the national output in some future year, this literature has failed to grasp the full impacts of increasing longevity on pension adequacy and financial sustainability. A failure to use pension wealth measures has led most studies to argue that pension transfers to future generations have been much reduced by recent reforms and that the latter have addressed large part of the additional financial costs induced by ageing. The analysis presented in this paper changes somewhat these conclusions, showing that while most governments have sought to reduce the future burden on taxpayers, increasing longevity means that the relative size of pension transfers will remain broadly similar - except in countries with very large projected spending (where policymakers have made more aggressive cuts). Looking at projected levels of pension wealth also indicates that some systems remain very vulnerable to longevity shocks.

Similarly our estimates show that the focus on modelling "full-careers" can be very misleading, particularly when looking at reforms which have tightened links between benefits and contributions. For instance, in Slovakia the poverty threshold achievable by pension transfers to low-income individuals could nearly halve when considering projected labour market participation rates. The "full-careers" assumption, by contrast, implies a drop of just a fifth. Rising labour participation in many cases can help undo a lot of the cuts in system generosity. The analysis in this paper, however, suggests that pensioner poverty may once again re-emerge as an important issue in some countries where at present its low level does not attract much political attention. Moreover in some cases, such in Eastern European countries, moves to link benefits with contributions may have serious gender equality implications. Policymakers need to be well aware of these risks and take them into account when designing sustainable reforms. Pension reforms of this kind need to be sustained by effective measures to increase labour market participation and to make sure individuals are aware of the new financial incentives/costs embedded in new pension systems. While clearly linking benefits to contributions makes sense to provide an effective and sustainable income smoothing function, policymakers also need to remain aware of the crucial poverty alleviation function of state pensions. 
While this paper has shed some light on these risks, there is scope for much more research. The hypothetical individuals used in this dissertation are an improvement on the standard full-career hypothetical cases, but they still fail to capture the intricacies of the real world. Policymakers would need to look at a wider variety of cases, particularly for different types of broken careers, and model more refined socioeconomic differences in labour participation. Another important modelling issue that this research has skirted is household formation and to what extent this makes a difference to the social sustainability indicators. For instance, no assessment was made of whether women's position would be better in some countries if one were to consider entitlement to their partners' pension. Similarly no attempt was made to allow non take-up of minimum pensions, or consider their interaction with private saving. Private provision was also assumed non-existent and this is a major simplification, particularly for some countries, notably the UK. Current provision and expected developments in this field have very important implications for the social sustainability of state pension systems.

Despite these very important analytical considerations, the social sustainability framework developed in this paper has enabled us to arrive at an improved understanding of whether the reforms conducted in Europe during the last decade will prove to be sustainable. It confirms that in many cases, there remains more to be done to address the financial requirements brought by the rapid ageing of Europe's population. It shows that when pressed, policymakers, particularly in Western Europe, were more willing to sacrifice the income smoothing function of pensions rather than poverty alleviation. This is a decision that makes considerable sense as middle- to high-income individuals are possibly in a better position to accommodate the effect of state pension reforms by increasing their private saving. In this regard, in view of the need to potentially decrease in absolute size the net pension wealth of future generations, policymakers in countries with the most severe pressures should consider further increases in state pension ages, complemented with an improvement in the labour market participation of older working age individuals. By maintaining the proportion of life spent in retirement unchanged across generations, policymakers would be better able to achieve similar system aims as under current systems. This would minimise the required increase in future financing requirements. At the same time, this analysis suggests that in some cases, notably in Eastern Europe, policymakers have abandoned the pursuit of the previous aims of their pension system and may not have fully considered the full impact of their policies on those on low incomes, on those with incomplete careers and on women. The required increase in private saving combined with the additional contributions required to finance public pensions appears to be too hefty for those on low incomes. Having a state pension which is able to alleviate poverty and provide a solid foundation for individuals to pursue their desired level of consumption smoothing will become even more important as the ageing transition progresses.

If tackled in a socially sustainable way, pension reform need not be as tortuous a process as it has been over the last decades. If policymakers agree on the aims they want their pension systems to achieve, and have the good sense to get political acceptance or at least make sure citizens are well informed of these aims, they will be able to set in place reforms that stand the test of time. The framework developed in 
this research presents one way in which policymakers can determine how best to structure their reforms. It shows the interaction between the achievement of system goals and pressure on system constraints, and is able to shed light on the effects of reforms on all groups of society. Pension systems have proven to be one of the most treasured social constructs of the twentieth century. There is little reason why they should not remain so also during the twenty-first century, if policymakers make the necessary modifications to assure their social sustainability. 


\section{References}

Barr, Nicholas and Peter Diamond (2006) "The economics of pensions", Oxford Review of Economic Policy, 22(1):15-39.

Economic Policy Committee (2007) Pensions schemes and projection models in EU25 Member States, European Economy Occasional Papers No. 35. Brussels: DG Economic and Financial Affairs.

Economic Policy Committee (2009) The 2009 Ageing Report: economic and budgetary projections for the EU-27 Member States (2008-2060). Brussels: DG Economic and Financial Affairs.

European Commission (2006), The long-term sustainability of public finances in the European Union, European Economy no 4/2006, Brussels: DG Economic and Financial Affairs.

European Commission (2009) Dealing with the impact of an ageing population in the $E U$, Communication from the Commission to the European Parliament, the European Economic and Social Committee and the Committee of Regions, COM (2009)/0180 final. Brussels: European Commission

Hering, Martin (2006) The politics of structural pension reform in Western Europe: Does the EU matter?, Paper presented at the Fifteenth International Conference of the Council for European Studies, March 29-April 2, 2006, Chicago: www.ces.columbia.edu/pub/papers/Hering.pdf

Holzmann, Robert and Richard Hinz (2005) Old-age income support in the 21st century: An international perspective on pension systems and reform. Washington D.C.: The World Bank.

Howse, Kenneth (2004) "What has fairness got to do with it? Social justice and pension reform", Ageing Horizons, 1: 3-16.

Martin, John P. and Edward Whitehouse (2008) Reforming retirement-income systems: Lessons from the recent experiences of OECD countries, Social, Employment and Migration Working Papers, DELSA/ELSA/WD/SEM (2008)3. Paris: OECD.

OECD (2005) Pensions at a glance 2005: Public policies across the OECD. Paris: OECD.

OECD (2007) Pensions at a glance 2007: Public policies across the OECD. Paris: OECD.

OECD (2009) Pensions at a glance 2009: Retirement-income systems in OECD countries. Paris: OECD.

Ove Moene, Karl and Michael Wallerstein (2003) "Earnings inequality and welfare spending: A disaggregated analysis", World Politics, 55: 485-516.

Schneider, Ondrej (2009) Reforming pensions in Europe: Economic fundamentals and political factors, CESifo Working Paper No. 2572. Munich: CESifo Group.

Whitehouse, Edward (2007) Pensions panorama: Retirement-income systems in 53 countries. Washington D.C.: The World Bank. 
World Bank (1994) Averting the Old-Age crisis: Policies to protect the old and promote growth. Oxford: Oxford University Press.

Zaidi, Asghar, Mattia Makovec, Michael Fuchs, Barbara Lipszyc, Orsolya Lelkes, Marius Rummel, Bernd Marin and Klaas de Vos (2006) Poverty of elderly people in EU25: First report. Vienna: European Centre for Social Welfare Policy and Research.

Zaidi, Asghar (2006) Pension policy in EU25 and its possible impact on elderly poverty, Policy Brief. Vienna: European Centre for Social Welfare Policy and Research.

Zaidi, Asghar and Aaron George Grech (2007) "Pension policy in EU25 and its impact on pension benefits", Benefits: The journal of poverty and social justice, 15(3): 229-311. 